\title{
Environmental Degradation and Human Rights Violation: A Cursory Overview of the Potential of the Existing Frameworks to Hold Multinational Corporations Accountable
}

\author{
Emmanuel Sarpong Owusu* \\ DOI: 10.21827/GroJIL.9.1.143-173
}

\begin{abstract}
Keywords
ENVIRONMENTAL DEGRADATION; EXTRATERRITORIAL JURISDICTION; HUMAN RIGHTS ABUSE; MULTINATIONAL CORPORATIONS; REGULATORY FRAMEWORKS
\end{abstract}

\begin{abstract}
It has been reported that an estimated 100,000 multinational corporations (MNCs) account for about a quarter of the global gross domestic product (GDP), generating a turnover which exceeds, by leaps and bounds, the public budget of many countries. Unfortunately, the manner of operation of the ever-expanding MNCs appears to engender rampant environmental degradation and wanton human rights violations in host nations. Even though frameworks aiming to regulate the activities of these corporations are in place, the effectiveness of the said regulatory mechanisms has been vociferously challenged, time and again, by academics and experts across the globe. Drawing on a range of pertinent case law as well as secondary sources, this article attempts to critically explore, and navigate, the extent to which the existing regulatory frameworks have been effective in holding MNCs accountable for their environment and human rights-related transgressions. The article establishes that the extant regulatory mechanisms have, to some extent, however miniscule, helped to promulgate awareness and inculcate environmental and human rights issues into corporate culture. It, however, demonstrates that these frameworks are grossly inadequate owing to the complex nature of the MNCs, the overtly broad and obscure nature of the existing international instruments and the reeking corruption in domestic political and judicial institutions. It recommends the codification of binding documents, backed by adequate compliance mechanisms, and the creation of an International Court having special jurisdiction over all MNCs.
\end{abstract}

\section{Introduction}

Over the last couple of decades, the world has witnessed a dramatic development and unprecedented expansion of multinational corporations (MNCs). ${ }^{1}$ The 2009 edition of the World Investment Report released by the United Nations Conference on Trade and Development (UNCTAD), recorded a global total of 889,416 MNCs. ${ }^{2}$ The global flows of foreign direct investment (FDI) in 2019 amounted to US $\$ 1.3$ trillion. ${ }^{3}$ According to the World Investment Report 2019, even though the FDI flows to developed economies reached the lowest point since 2004, declining by a steep 27 per cent in 2019, the flows to

Emmanuel Sarpong Owusu, PhD Candidate, Department of Law and Criminology, Aberystwyth University, Wales, United Kingdom. Email: es.owusu@yahoo.co.uk; eso2@aber.ac.uk

1 United Nations Conference on Trade and Development (UNCTAD), World Investment Report 2009: Transnational Corporations, Agricultural Production and Development (UNCTAD 2009).

ibid.

3 United Nations Conference on Trade and Development (UNCTAD), World Investment Report 2019: Special Economic Zones (UNCTAD 2019).

This work is licensed under the Creative Commons Attribution-NonCommercial-NoDerivatives 4.0 International License.

To view a copy of this license, visit http://creativecommons.org/licenses/by-nc-nd/4.0/. 
developing countries such as those in Africa and Asia remained stable, rising by 2 per cent. The report further suggests that FDI flows to Africa rose by 11 per cent to US $\$ 46$ billion in 2019.4 It has been reported that an estimated 100,000 MNCs account for about a quarter of the global gross domestic product (GDP), ${ }^{5}$ generating a turnover which exceeds the public budget of many countries. ${ }^{6}$ It is therefore hardly surprising that these corporations, which are indubitably the key players and drivers of today's globalised economy, have grown and continue to grow, not only in number, but also in power and influence. ${ }^{7}$ However, the continual expansion of MNCs, the massive geographical spread of their operations, and the multiplicity of the activities involved, have evoked environmental and human rights concerns among scholars, experts, activists and, indeed, the general public.

Globalisation, as Shelton notes, has 'created powerful non-state actors that may violate human rights in ways that were not contemplated during the development of the modern human rights movement. ${ }^{8}$ Thus, the operations of MNCs do, many a time, result in extremely detrimental environmental consequences and, consequently, tangible human rights violations. ${ }^{9}$ Ipso facto, there are several notable frameworks and mechanisms aimed at regulating the activities of these corporations and holding them accountable for the environmental slander and human rights infringement they inflict. But the efficacy of these frameworks has been repeatedly questioned by various esteemed academics and experts, as environmental damage and human rights violations appear to be escalating rather than subsiding, particularly in the developing countries. ${ }^{10}$ This has compelled Chesterman to assert that the regulatory frameworks appear an 'illusion ... which may be

ibid.

United Nations Conference on Trade and Development (UNCTAD), World Investment Report: NonEquity Modes of International Production and Development (UNCTAD 2011).

6 John Mikler, 'Global Companies as Actors in Global Policy and Governance' in John Mikler (ed), The Handbook of Global Companies (Wiley-Blackwell 2013) 1.

7 Alison Shinsato, 'Increasing the Accountability of Transactional Corporations for Environmental Harms: The Petroleum Industry in Nigeria' (2005) 4(1) Northwestern Journal of International Human Rights 186; Peter Muchlinski, 'Multinational Enterprises as Actors in International Law: Creating "Soft Law" Obligations and "Hard Law" Rights' in Math Noortmann and Cedric Ryngaert (eds), Non-State Actor Dynamics in International Law: From Law-Takers to Law-Makers? (Ashgate 2010) 9.

8 Dinah Shelton, 'Protecting Human Rights in a Globalized World' (2002) 25 Boston College International and Comparative Law Review 273, 279.

9 Jana Silverman and Alvaro Orsatti, 'Holding transnational corporations accountable for human rights obligations: the role of civil society' (2009) Social Watch < https://www.socialwatch.org/node/812> accessed 28 August 2021; Daniel Augenstein, Alan Boyle, David Cabrelli, James Harrison, Navraj Singh Ghaleigh and Elisa Morgera, Study of the Legal Framework on Human Rights and the Environment Applicable to European Enterprises Operating Outside the European Union (University of Edinburgh 2010); Itzhak Ben-David, Yeejin Yang, Stefanie Kleimeier and Michael Viehs, 'Exporting Pollution: Where Do Multinational Firms Emit CO2?' (2020) European Corporate Governance Institute - Finance Working Paper 717/2020 <https://ssrn.com/abstract=3252563> accessed 10 June 2021

10 Alexandra Gatto, Multinational Enterprises and Human Rights: Obligations under EU Law and International Law (Elgar 2011); Jan Wouters and Anna-Luise Chané, 'Multinational Corporations in International Law' (2013) KU Leuven Working Paper 129 <https://ssrn.com/abstract=2371216> accessed 14 April 2020; Barnali Choudhury, 'Balancing Soft And Hard Law for Business and Human Rights' (2018) 67(4) International \& Comparative Law Quarterly 961; Prasadi Wijesinghe, 'Environmental Pollution and Human Rights Violations by Multinational Corporations' (SSRN 2018) <http://dx.doi.org/10.2139/ssrn.3164142>; Mallika Tamvada, 'Corporate social responsibility and accountability: a new theoretical foundation for regulating CSR' (2020) 5(2) International Journal of Corporate Social Responsibility 1; Nils Muižnieks, 'Multinationals Seem Too Big for Accountability: Switzerland May Change That' (Amnesty International, 27 November 2020) https://www.amnesty.org/en/latest/news/2020/11/multinationals-seem-too-big-for-accountabilityswitzerland-may-change-that/> accessed 29 April 2020. 
worse than no regulation at all' ${ }^{11}$ This article, thus, seeks to critically evaluate the effectiveness of the existing frameworks, at the regional, national and international levels, in modulating the operations of the MNCs and rendering them accountable for unethical environmental practices and human rights violations in host States.

To achieve the defined aim, the article, drawing on not only a range of cases and judicial mandates but also secondary sources, briefly explains the term, 'multinational corporations', highlighting some of their key positive and negative economic aspects and prospects. This is followed by an identification and succinct description of some of the general negative impacts of the operations of MNCs on the environment and human rights. Efforts have been made to pinpoint and briefly elucidate the key mechanisms and instruments that are currently in place to regulate the activities of the MNCs. The second part of the article critically explores the extent to which the existing regulatory frameworks have been effective in monitoring the operations of MNCs and holding them accountable for any environmental degeneration and human rights' breaches that they may happen to be involved in, directly or indirectly, in host States. It proposes a couple of measures for the effective monitoring of the MNC operations. Finally, a conclusion, recapitulating the key points, is arrived at.

\section{Multinational Corporations and their Impacts}

The term, 'multinational corporation' (MNC), also known as 'transnational corporation' (TNC), has been defined as 'an economic entity operating in more than one country or a cluster of economic entities operating in two or more countries - whatever their legal form, whether in their home country or country of activity, and whether taken individually or collectively. ${ }^{12}$ Drawing on Vernon, ${ }^{13}$ Ferdausy and Rahman state that MNCs 'represent a cluster of affiliated firms located in different countries that are linked through common ownership, draw upon a common pool of resources, and respond to a common strategy'. ${ }^{14}$ The essence of an MNC, thus, lies in the fact that it establishes offices or factories and operates in several countries (known as the 'host' countries) despite being centralised and headquartered in just one single country (referred to as the 'home' country), where it monitors and coordinates global management. ${ }^{15}$ The end goal of MNCs is to make profits. ${ }^{16}$ According to Wouters and Chané, a distinctive feature of contemporary MNCs is that they "have the capacity to flexibly move places of production and assets between countries. They structure management units independently of national borders and lose every tie to a nation state except for the formal nexus of

11 Simon Chesterman, 'Lawyers, Guns, and Money: The Governance of Business Activities in Conflict Zones' (2010/2011) 11(2) Chicago Journal of International Law 321, 324.

12 UN Sub-commission on the Promotion and Protection of Human Rights, 'Norms on the Responsibilities of Transnational Corporations and Other Business Enterprises with regard to Human Rights' (26 August 2003) 55th Session UN Doc E/CN.4/Sub.2/2003/12/Rev.2., para 20.

13 Raymond Vernon, 'Sovereignty at Bay: The multinational spread of U.S. enterprises' (1971) 13 The International Executive <https://doi.org/10.1002/tie.5060130401>

14 Shameema Ferdausy and Sahidur Rahman, 'Impact of Multinational Corporations on Developing Countries' (2009) 24 The Chittagong University Journal of Business Administration 111, 115; See also Yao-Su Hu, 'Global or Stateless Corporations are National Firms with International Operations' (1992) 34(2) California Management Review 107.

15 Gary Z Nothstein and Jeffrey P Ayres, 'The Multinational Corporation and the Extraterritorial Application of the Labor Management Relations Act' (1976) 10 Cornell International Law Journal 1; Ferdausy and Rahman (n 14); Hu (n 14).

16 Isabella D Bunn, 'Global Advocacy for Corporate Accountability: Translantic Perspectives from the NGO Community' (2004) 19(6) American University International Law Review 1265; Hu (n 14). 
incorporation. ${ }^{17}$ It is further maintained that ' $[t]$ his operational fluidity and the ensuing detachedness from domestic bounds are one of the main reasons why national legislators fail to put adequate checks on the power of MNCs, and why MNCs have moved into the focus of international law. ${ }^{18}$

There is no denying that MNCs have a wide range of socio-economic benefits, and play a pretty significant role in the developmental, technological and financial upliftment of the host nations. ${ }^{19}$ This, perhaps, explains why nations adopt aggressive but usually less stringent policies to allure and retain foreign investors. ${ }^{20}$ One of the obvious economic benefits of MNCs to host countries is the creation of jobs or the stimulation of domestic employment, which may ultimately enhance the quality of life of domestic employees. ${ }^{21}$ Another important benefit is the injection of capital unto the State through FDI, which evidently helps to revitalise an economy through improved productivity, growth, and exports. MNCs may also facilitate the development and/or enhancement of innovative technology, effective business practices, marketing and communication skills, inter alia. ${ }^{22}$ It is also known that they create well-paid jobs as well as technologically advanced products, particularly, in developing States that otherwise would not have access to such opportunities. ${ }^{23}$ Some Corporations even expand into traditionally Staterun sectors, fulfilling governmental functions to some extent by providing infrastructure, housing, and educational and health services; ${ }^{24}$ however, it is not being suggested here that such conduct necessarily entails governmental authority. It is also eminently obvious that the presence of the MNCs in the host nations may contribute immensely to the integration of these countries to the global economy through increased exports, trade, and communication. ${ }^{25}$

This is not to suggest that the operations of MNCs do not have any negative economic repercussions for host nations. Some experts have expressed concerns about significant challenges that MNCs could pose for domestic businesses, poignantly their possible decline and disintegration, due to their inability to compete with MNCs, which consequently acquire them at a throwaway price. ${ }^{26}$ Again, lack of stringent control measures by host countries may result in tax avoidance or evasion by MNCs, particularly in developing countries. ${ }^{27}$ But the most alarming and calamitous aspects of the operations of MNCs, on which this article focuses, are their deleterious impact on the environment and severe violation of human rights in host countries. ${ }^{28}$ As Silverman and Orsatti

17 Wouters and Chané (n 10) 6.

18 ibid.

19 Olivier De Schutter, Jan Wouters, Philip De Man, Nicolas Hachez and Matthias Sant'Ana, 'Foreign Direct Investment, Human Development and Human Rights: Framing the Issues' (2009) 3 Human Rights and International Legal Discourse 137.

20 Wouters and Chané (n 10); Jan Wouters and Cedric Ryngaert, 'Litigation for Overseas Corporate Human Rights Abuses in the European Union: The Challenge of Jurisdiction' (2009) 40(4) The George Washington International Law Review 939.

21 Nothstein and Ayres (n 15); Ferdausy and Rahman (n 14).

22 Gatto (n 10) 4; Bunn (n 16) 1269; Ferdausy and Rahman (n 14).

23 Ferdausy and Rahman (n 14).

24 Gatto (n 10) 4; See also Bunn (n 16) 1269.

25 Joseph M Grieco and Gilford Jonhn Ikenberry, State Power and World Markets: The International Political Economy (Norton \& Company 2003).

26 Ferdausy and Rahman (n 14); Sol Picciotto, 'Rights, Responsibilities and Regulation of International Business' (2003) 42 Columbia Journal of Transnational Law 131, 148.

27 Picciotto (n 26); John Stopford, 'Multinational Corporations' (1998) 113 Foreign Policy 12.

28 Silverman and Orsatti (n 9); Stopford (n 27); Aniefiok E Ite, Usenobong F Ufot, Margaret U Ite, Idongesit $\mathrm{O}$ Isaac and Udo J Ibok, 'Petroleum Industry in Nigeria: Environmental Issues, National Environmental Legislation and Implementation of International Environmental Law' (2016) 4 American Journal of Environmental Protection 21. 
observe, 'the proliferation of investments by multinational enterprises in developing countries over the last decades has had profound social and environmental impacts, to the point where some multinationals have been complicit in gross violations of fundamental human, social, labour and environmental rights. ${ }^{29}$ It is therefore imperative to highlight, concisely yet comprehensively, how and where the operations of MNCs impinge the environment and vilify human rights.

\section{A. Negative Impact of MNCs' Activities on the Environment and Human Rights}

One of the major environmental problems caused by the activities of MNCs is air pollution, which usually results from the emission of noxious gases and has colossal health implications. ${ }^{30}$ For instance, the unlawful practice of gas flaring creates massive plumes of fire and smoke, releasing a mixture of toxic chemicals which has been linked to increased occurrences of cancer and respiratory ailments. ${ }^{31}$ There have also been umpteen incidences of oil spillage and inappropriate disposal of waste, leading to severe and irrevocable pollution of farmlands, wells, streams and rivers, besides the profligate annihilation of thousands of hapless aquatic creatures and the delicate mangrove forests. ${ }^{32}$ For example, over the past five decades, the oil-producing host communities in Nigeria's Niger Delta region have, according to Ite and others, 'experienced a wide range of environmental pollution, degradation, human health risks and socio-economic problems as a result of activities associated with petroleum exploration, development and production ${ }^{33}$ It is asserted that, on average, major oil spills are recorded thrice a month in the Niger Delta, and that about 4,835 oil spills were recorded in the same oil-rich region between 1976 and $1996 .{ }^{34}$ Such environmental hazards are usually the direct result of poor environmental, health and safety, and human resource management practices; or sheer negligence. ${ }^{35}$ There have been endless complaints of lack of proper maintenance and housing of equipment, and rampant disposal of toxins into the waterbodies by MNCs in implicit and explicit collusion with hoodlums and criminals. ${ }^{36}$

As rural communities (especially in developing countries) rely primarily on fishing and farming for subsistence, and as rivers and streams provide water for domestic uses, most importantly drinking, the pollution of rivers, streams, and farmlands tends to adversely affect not only the environment, but also the health and socio-economic life of the people, as evidenced in the Anderson et al v WR Grace and Beatrice Foods ${ }^{37}$ and Wiwa v Royal Dutch Petroleum/Shell ${ }^{8}$ cases. Environmental pollution or destruction, as Shinsato

29 Silverman and Orsatti (n 9).

30 Shinsato (n 7).

31 ibid 194.

32 ibid 186; Nigerian Environmental Study/Action Team (NEST), Nigeria's Threatened Environment: A National Profile (NEST 1991).

33 Ite and others (n 28).

34 Shinsato (n 7).

35 ibid.

36 ibid.

37 Anderson et al v W R Grace \& Beatrice Foods, 628 F Supp 1219 (D Mass. 1986); See also Lewis Grossman, Robert G Vaughn and Jonathan Haar, A Documentary Companion to A Civil Action (Foundation Press 1999); Jonathan Haar, A Civil Action (Random House 1995)

38 Wiwa v Royal Dutch Petroleum/Shell 226 F.3d 88 (2d Cir. 2000), cert. denied, 532 US 941 (2001); This case will be looked at in more detail later in the discussion. 
emphasises, may also compel the local populace to become environmental refugees or environmentally displaced people as they are compelled to leave the contaminated environment for a more habitable place. ${ }^{39}$ This was the case during the Bhopal dissaster where a methyl isocyanate gas leak from a Union Carbide plant in Bhopal, India, resulted in the death of over 3,500 people, and exposed more than 550,000 individuals to the poisonous gas. ${ }^{40} \mathrm{MNCs}$ may directly violate human rights in host nations in other ways such as the employment of children (child labour); the exploitation of their indigenous workforce (e.g., paying low wage); using discriminatory recruitment, training and promotion policies; adopting poor health and safety standards at the workplace; generating undue constant noise; and endangering the lives and health of the local people as a result of the damaged environment. ${ }^{41}$ There have also been instances where MNCs have indirectly created incentives for State authorities to violate human rights for business purposes, or financially and logistically supported regimes engaged in human rights violations such as torture and murder as alleged in Wiwa. ${ }^{42}$

The aforementioned facts, and other evidence, demonstrate the profound and inextricable link betwen the environment and human rights. ${ }^{43}$ It could, in fact, be argued that a safe and healthy environment is an essential requirement for the enjoyment of fundamental human rights, as the polution or destruction of the natural environment of a community always tends to have greater disturbing human rights implications. MNCs' harmful and unethical practices have therefore called for a revitalisation of the concept of Corporate Social Responsibility (CSR), which 'describes the expectation that corporate operations and strategies be conducted "in ways that respect ethical values, people, communities and the environment", "44 and which encourages the intensification of efforts to hold MNCs accountable for the negative impact of their commercial activities in host countries. ${ }^{45}$

\section{B. Relevant Regulatory and Accountability Frameworks}

In order to mitigate potential corporate harms such as those elucidated above, accountability frameworks are needed; and work on building such measures began decades ago. ${ }^{46}$ Therefore, before the extent of the efficacy of these regulatory and accountability mechanisms is explored, it is considered expedient to identify and succinctly describe some of the relevant or key ones.

39 Shinsato (n 7) 188.

40 Edward Broughton, 'The Bhopal disaster and its aftermath: a review' (2005) 4(6) Environmental Health: A Global Access Science Source 1; Clayton R Trotter, Susan G Day and Amy E Love, 'Bhopal, India and Union Carbide: The Second Tragedy' (1989) 8(6) Journal of Business Ethics 439; Ingrid Eckerman, The Bhopal Saga - Causes and Consequences of the World's Largest Industrial Disaster (Universities Press, 2005).

41 Wouters and Chané (n 10); Ferdausy and Rahman (n 14); Picciotto (n 26) 148.

42 Wouters and Chané (n 10); Wiwa (n 38).

43 Alan Boyle, 'Human Rights and the Environment: Where Next?' (2012) 23(2) The European Journal of International Law 613.

44 Bunn (n 16) 1272.

45 ibid; Nancy Lee and Philip Kotler, Corporate social responsibility doing the most good for your company and your cause (Wiley 2013); Benedict Sheehy, 'Understanding CSR: An Empirical Study of Private Regulation' (2012) 38 Monash University Law Review 103; Kirsten Stefanik, 'Rise of the Corporation and Corporate Social Responsibility: The Case for Corporate Customary International Law' (2017) 54 Canadian Yearbook of International Law 276.

46 Connie de la Vega, Amol Mehra and Alexandra Wong, 'Holding Businesses Accountable for Human Rights Violations', Global Policy and Development and Dialogue on Globalization (Friedrich-Ebert-Stiftung 2011). 
As a matter of fact, the initiative to address the accountability of MNCs was begun by the United Nations (UN) in 1972, when its Economic and Social Council ordered a study of the role of MNCs and their impact on the development process as well as on international relations. ${ }^{47}$ That request led to the establishment of the UN Centre on Transnational Corporations (UNCTC) in December 1974 as an advisory body. ${ }^{48}$ One of UNCTC's aims, as Vega and others note, was to secure 'international arrangements that promoted the positive contributions of transnational corporations' ${ }^{49}$ It completed a first draft of an international code of conduct for MNCs - the UN Draft Code of Conduct on Transnational Corporations in 1990 after its commencement in 1978. The Draft Code was never adopted before the UNCTC's responsibilities were transferred to the UNCTAD in $1993 .^{50}$ The prime goals of UNCTAD, which was established by the UN General Assembly in 1964, are to 'maximize the trade, investment and development opportunities of developing countries and assist them in their efforts to integrate into the world economy on an equitable basis'. ${ }^{51}$ It also formulates policies that relate to all aspects of development, including trade, investment, transport, finance and technology. The UNCTAD prepares several important reports, including the Trade and Development Report, the Trade and Environment Review, the World Investment Report, and the Economic Development in Africa Report, among others. ${ }^{52}$ The year 2000 witnessed the promulgation of the UN Global Compact, a multi-stakeholder initiative committing corporations to respect international principles pertaining to human rights, labour rights, environmental issues, and anti-corruption practices. ${ }^{53}$ Mention should be made of the Norms on the Responsibilities of Transnational Corporations and Other Business Enterprises with Regard to Human Rights (hereinafter the Norms) formulated in 2003 by the UN Sub-Commission on the Promotion and Protection of Human Rights. ${ }^{54}$ The Norms were a valuable articulation of obligations of corporations to respect the environment and human rights, for they called for greater accountability of MNCs. ${ }^{55}$

The UN Guiding Principles on Business and Human Rights (hereinafter the Principles), drafted in 2011, too, deserves a noteworthy acknowledgement. It is one of the first UN endorsed instruments that is not only meant to directly address the adverse impacts of MNCs' activities, but also applies to all States and business enterprises. The Principles which were formulated under the leadership of John Ruggie encompass respect for human rights and the environment and other ethical behaviours. States are also required to provide effective access to remedy such as State and non-state-based

47 UN Economic and Social Council 'The impact of multinational corporations on the development process and on international relations' (28 July 1972) ESCOR 53rd Session Supp 1 UN Doc E/RES/1721(LIII).

48 See Vega and others (n 46) 2.

49 ibid.

50 ibid.

51 UNCTAD, Guide for Delegates (2019) UN Doc UNCTAD/ISS/MISC/2019/4 $<$ https://unctad.org/en/PublicationsLibrary/issmisc2019d4_en.pdf $>$ accessed10 June 2020.

52 UNCTAD, 'About UNCTAD' <https://unctad.org/en/Pages/aboutus.aspx> accessed 10 April 2020.

53 'The Ten Principles of the UN Global Compact' (United Nations Global Compact) $<$ https://www.unglobalcompact.org/what-is-gc/mission/principles> accessed 10 June 2020; See also Wouters and Chané (n 10).

54 UN Sub-commission on the Promotion and Protection of Human Rights (n 12).

55 ibid para 15; See also David Weissbrodt and Muria Kruger, 'Norms on the Responsibilities of Transnational Corporations and Other Business Enterprises with Regard to Human Rights' (2003) 97(4) American Journal of International Law 901. 
grievance and judicial mechanisms. ${ }^{56}$ The International Labour Organisation's (ILO) general regulatory activity also embraces broader issues on social policy and MNCs contribution to the societies in which they operate. The formulation of the ILO Tripartite Declaration of Principles concerning Multinational Enterprises and Social Policy adopted by the Governing body of the ILO in November 1977 has been quite significant. ${ }^{57}$ One of the key goals of the Declaration, as the preamble indicates, is the promotion of the enjoyment of human rights. ${ }^{58}$

Another important body is The Organisation of Economic Cooperation and Development (OECD). Even though the OECD (which currently comprises about 36 member countries) focuses mainly on the promotion and protection of the interests of foreign investment, it has developed guidelines - OECD Guidelines for Multinational Enterprises (adopted by all OECD Member States in 1976) aimed at curtailing the grandiosities and excesses of MNCs. ${ }^{59}$ The current OECD Guidelines contain important provisions on human rights, workers and wages, and climate change; besides, it stresses the need for MNCs to behave in a way that is ethical. ${ }^{60}$ Also of some significance is the International Trade Union Confederation (ITUC) which seeks to promote and defend 'workers' rights and interests, through international cooperation between trade unions, global campaigning and advocacy within the major global institutions' ${ }^{61}$ Besides, various NGOs have been campaigning for codes of conduct for businesses. Some of such initiatives are, Amnesty International's Human Rights Principles for Companies, the Ethical Trading Initiative, Principles of Global Corporate Responsibility, and many others. $^{62}$

Unfortunately, international and regional frameworks or mechanisms, including those highlighted above, form part of what is commonly known as 'soft law' and are thus not binding on MNCs. This, as it shall be argued and demonstrated later in this discussion, poses a huge challenge in effectively regulating the operations of MNCs and holding them accountable for various excesses and abuses at the international level. For this reason, domestic regulatory frameworks have become very important in the fight against environmental degradation and human rights abuses caused by MNCs. Indeed, each country on earth has its own mechanisms aimed at regulating the operations of MNCs within its jurisdiction and ensuring compliance with its laws. But special mention must be made of the US Alien Tort Claims Act (ATCA) also known as the Alien Tort Statute (ATS) ${ }^{63}$ This Act provides district courts with jurisdiction ratione materiae for 'any civil action by an alien for a tort only, committed in violation of the law of nations or a

56 UNHRC 'Report of the Special Representative of the Secretary-General on the Issue of Human Rights and Transnational Corporations and other Business Enterprises, John Ruggie: Guiding Principles on Business and Human Rights: Implementing the United Nations "Protect, Respect and Remedy" Framework' (21 March 2001) UN Doc A/HRC/17/31.

57 ILO, 'Tripartite Declaration of Principles Concerning Multinational Enterprises and Social Policy', ILO Doc. 28197701, OB Vol. LXI, 1978, ser. A, No. 1 (1977), amended by the Governing Body of the International Labour Office at its 279th (November 2000), 295th (March 2006) and 329th (March 2017) Sessions.

58 ibid section 1.

59 Claes Hägg, 'The OECD Guidelines for Multinational Enterprises A critical Analysis' (1984) 3 Journal of Business Ethics 71.

60 OECD, Guidelines for Multinational Enterprises (OECD Publishing 2011).

61 'The International Trade Union Confederation (ITUC) is the global voice of the world's working people' (ITUC CSI IGB) <https://www.ituc-csi.org/about-us> accessed 20 July 2019; see also Human and Trade Union Rights Committee, 'Countries at Risk Report', International Trade Union Confederation, Brussels (2019).

62 Bunn (n 16) 1288-1289.

63 The Alien Tort Claims Act (ATCA) of 1789,USC $\S 1350$. 
treaty of the United States' ${ }^{64}$ Thus, based on the precept of universal jurisdiction for crimes involving the 'law of nations', this legislation presumably entitled US courts to rule on cases involving gross violations of human rights regardless of the location and nationality of the perpetrators and their victims.$^{65}$ This was reiterated in Sosa v AlvarezMachain in which the US Supreme Court affirmed jurisdiction for violations of those international norms which are 'specific, universal, and obligatory'. ${ }^{66}$ Until 2013, this instrument was exploited frequently by a number of foreign activists and claimants. However, its use was considerably restricted by the Supreme Court in 2013, as it shall be shown later in this discussion.

The important question that should now be addressed is how effective the aforenamed regional, national and international bodies and instruments have been in regulating the operations of MNCs and holding them accountable for their environmental and human rights related transgressions.

\section{The Efficacy of Existing Regulatory Frameworks}

\section{A. The Strengths/Successes of Extant Regulatory Frameworks}

There is not an iota of doubt that significant success has been realised by the existing accountability framework. Many of the structures, including the UNCTC and UNCTAD, have been legitimately successful in furthering understanding of the political, economic, social, and legal effects of the operations of MNCs, and campaigning against the overbearing and unethical behaviour of $\mathrm{MNCs} .{ }^{67} \mathrm{~A}$ number of the mechanisms, including the Guiding Principles, have been lauded for successfully creating awareness about the problem and establishing a clear demarcation between State obligations and corporate responsibilities. ${ }^{68}$ Other instruments, particularly the OECD Guidelines, provide some form of complaints avenue (e.g., National Contact Points) where proceedings could be initiated against MNCs for non-compliance with the Guidelines. The existing framework, though generally non-binding, may be regarded as a precursor for binding rules. The outcomes of the Rights and Accountability in Development (RAID) $v$ Das Air and Global Witness v Afrimex cases ${ }^{69}$ which were dealt with by the UK National Contact Point (NCP), merit special mention here. In these two cases, the UK NCP concluded that both Das Air and Afrimex had failed to meet the requirements of the OECD Guidelines, and also affirmed and stressed the need for all UK multinational enterprises to abide by international norms, standards, and conventions, including the

6428 US Code § 1350; also cited in Wouters and Chané (n 10) 20.

65 Silverman and Orsatti (n 9); Douglas M Branson, 'Holding Multinational Corporations Accountable? Achilles' Heels in Alien Tort Claims Act Litigation' (2011) 9 Santa Clara Journal of International Law 227, 228.

66 Sosa v Alvarez-Machain 542 US 692 (2004) 331 F3d 604.

67 See Susan Ariel Aaronson and Ian Higham, "Re-righting Business": John Ruggie and the Struggle to Develop International Human Rights Standards for Transnational Firms' (2013) 35 Human Rights Quarterly 333.

68 ibid 336.

69 Larry Catá Backer, 'Rights and Accountability in Development (RAID) v Das Air and Global Witness v Afrimex' (2009) 10 Melbourne Journal of International Law; In 2005, RAID lodged a complaint with the UK National Contact Point (NCP) for the OECD Guidelines for Multinational Enterprises against Das Air (a UK-registered company), accusing the company of violating certain OECD Guidelines by playing a role in the Ugandan invasion of Democratic Republic of Congo (DRC) territory. In February 2007, Global Witness also filed a complaint against Afrimex (also a UK-registered company) alleging that Afrimex paid taxes to rebel forces in the DRC and that it failed to practice due diligence regarding its supply chain because it sourced minerals from mines that used child labour. 
Convention on International Civil Aviation (also known as the Chicago Convention) ${ }^{70}$ which establishes rules of airspace as well as aircraft registration and safety, security, and sustainability. The UK NCP even went to the extent of adopting UN Security Council Resolution 1592 as a 'business requirement' that companies operating in the UK must observe despite the fact that the Resolution is intended for nations, not non-state entities. ${ }^{71}$ The accused companies, particularly Afrimex offered to formulate a corporate responsibility document under which it would operate in the future. These two decisions of the UK NCP underpin the growing importance of the OECD Guidelines in influencing corporate behaviour across territorial borders, in particular, holding corporations responsible for the actions of third parties in their supply chain if they fail to apply a due diligent check on the said supply chain.

One of the other important triumphs of the existing frameworks has been the outcome of the Doe $v$ Unocal $^{72}$ case initiated in 1997 in a US court under the ATCA. The case centred on alleged human rights offences perpetrated during the construction of the Yadana pipeline in Myanmar. On September 18, 2002, the US Court of Appeals reversed an earlier decision by a district court and declared that the lawsuit against Unocal could go to trial as it was satisfied that the claimants had presented enough evidence to support their allegations. A jury trial on the claimants' claims of murder, rape, and forced labour was accordingly scheduled for June of 2005. But in March of 2005, Unocal agreed to compensate the aggrieved parties in a historic settlement that ended the lawsuit. Another significant success story of the extant frameworks is the Wiwa case which consisted of three separate lawsuits brought by the family of Ken Saro-Wiwa and other Ogoni activists against Royal Dutch/Shell and its subsidiary, Shell Petroleum Development Company of Nigeria Limited (SPDC), in a US federal court under the ATCA. ${ }^{73}$ The claimants won several pre-trial rulings. ${ }^{74}$ These developments compelled Shell to pay out US\$15.5 million out-of-court settlement in early June 2009. Shell also agreed to establish the Kiisi Trust, intended to benefit the Ogoni people in areas such as education, women's programmes, adult literacy, and small enterprise support. ${ }^{75}$

The $M V$ Erika $^{76}$ oil spill case is also worthy of note. In December 1999, the poorly serviced tanker, Erika, sank approximately 50 miles off the coast of Brittany, dumping

70 Convention on International Civil Aviation (adopted 7 December 1944, entered into force 4 April 1947) 15 UNTS 295, as amended by ICAO Doc 7300/9 (2006).

71 Statement by the United Kingdom National Contact Point (NCP) for OECD Guidelines for Multinational Enterprises: DAS Air (21 July 2008) (Final Statement) <http://www.berr.gov.uk/files/file47346.doc> accessed 20 July 2020; RAID (n 69).

72 Doe v Unocal Corp. 963 F Supp 880 (CD Cal 1997), dismissed in part, 110 F Supp 2d 1294 (CD Cal 2000), aff'd in part, rev'd in part, 395 F3d 932 (9th Cir 2002), opinion vacated and rehearing en banc granted, 395 F3d 978 (9th Cir. 2003).

73 Wiwa (n 38); The plaintiffs accused Shell of colluding with government forces in crimes against humanity and gross human rights violations, including torture and the execution of the ace Nigerian writer and activist Ken Saro-Wiwa and several other activists in 1995.

74 'US court backs anti-Shell lawsuit' (BBC News, $26 \quad$ March 2001) <http://news.bbc.co.uk/1/hi/world/americas/1244434.stm> accessed 10 July 2020.

75 Chris Kahn, 'Settlement Reached in Human Rights Cases against Royal Dutch Shell' (Global Policy Forum, 08 June 2009) <www.globalpolicy.org/international-justice/alien-tort-claimsact-630/47879.html> accessed 15 August 2019.

76 Tribunal Correctionnel de Paris (Jugement) No 9934895010 (16 January 2008); see also 'Permanent Commission of Enquiry into Accidents at Sea, 'Report of The Enquiry into the Sinking of the Erika off the Coasts of Brittany on 12 December 1999'; Matthew Saltmarsh, 'French Court Upholds Verdict in Oil Spill', New York Times (New York, $30 \quad$ March 2010) <http://www.nytimes.com/2010/03/31/business/energy-environment/31total.html?> accessed 20 July 2020; BBC, 'France upholds Total verdict over Erika oil spill' (BBC, 25 September 2012) <http://www.bbc.co.uk/news/world-europe-19712798> accessed 10 January 2019. 
30,000 barrels of oil into the sea, and contaminating about $400 \mathrm{~km}$ of coastline. This caused a considerable impact, particularly, on the fisheries and tourism businesses in the area. In January 2008, a French Criminal Court in Paris, relying on the relevant legal instruments, found the oil giant, Total (the charterer of the tanker) and related parties (i.e. owners and managers) liable for the damage caused by the incident. ${ }^{77}$ Total appealed, but in 2010, a French appeals court upheld the earlier ruling that Total and the related parties were equally responsible for the huge environmental damage caused by the oil spill from Erika. ${ }^{78}$ Total was fined $€ 375,000$ and ordered to pay nearly $€ 200$ million in damages to the French State, the local fishing industry, and other relevant environmental groups. This ruling, as Saltmarsh notes, has, to a significant extent, caused the European Union to tighten or impose new controls on its maritime safety, including the elimination of single-hull tankers like the Erika. ${ }^{79}$

In August 2006, the ship, Probo Koala, chartered by Trafigura or its affiliate, offloaded more than 500 tons of toxic waste at the Port of Abidjan, Ivory Coast. This toxic material was then recklessly dumped at various locations in the city and surrounding areas by a local subcontractor. The reckless and unethical disposal of the extremely hazardous material caused serious injuries to tens of thousands of people and severe damage to the environment. In November 2006, legal proceedings involving about 30,000 claimants were filed with the UK courts against Trafigura Limited (a UK company) and Trafigura Beheer BV (a company incorporated in the Netherlands) for their role in the disaster. The claimants argued that the Trafigura group had chartered the ship and had ordered it to proceed with its toxic cargo to the Ivory Coast when they knew or ought to have known that the material aboard was dangerous to human health, and that the local contractor was not properly resourced and was unqualified to dispose of the hazardous substance safely. Trafigura disputed the claimants' allegations; however, in September 2009 the claim was settled out of court before the matter went to trial, without any admissions of liability by Trafigura. ${ }^{80}$ It should however be mentioned that the Ivorian domestic legal system's handling of this case was quite disappointing as it shall be shown later in this discussion.

BP has also been ordered by US courts to pay billions of dollars in compensation for the 20 April 2010 explosion from its Deepwater Horizon Well off the coast of Louisiana that killed 11 workers, releasing an estimated 4 million barrels of oil into the Gulf, and causing widespread environmental damage including the crippling of the fishing and seafood industry and regional tourism. It is reported that hundreds of lawsuits, many of which are class actions, have been and are still being filed with US

77 Tribunal Correctionnel de Paris (Jugement) No 9934895010 (16 January 2008); Saltmarsh (n 76); BBC (n 76).

78 Cour d'Appel de Paris (Jugement) Pôle 4, Chamber 11E, RG n 08/02278 (30th March 2010).

79 Saltmarsh (n 76).

80 Amnesty International and Greenpeace, The Toxic Truth: About a company called Trafigura, a ship called the Probo Koala, and the dumping of toxic waste in Côte d'Ivoire (Amnesty International Publications 2012); see also Jennifer A Zerk, 'Extraterritorial jurisdiction: lessons for the business and human rights sphere from six regulatory areas' (2010) Corporate Social Responsibility Initiative, Harvard University Working Paper

<https://www.hks.harvard.edu/sites/default/files/centers/mrcbg/programs/cri/files/workingpaper> accessed 10 April 2020. 
courts against BP under various relevant domestic human rights and environmental legal instruments such as the Clean Water Act and Oil Spill Pollution Act. ${ }^{81}$

In a limited number of cases, developing countries have been able to hold parent companies liable for the environmental and human rights transgressions of their subsidiaries, using domestic legal frameworks. For instance, following the Bhopal disaster in 1984, Union Carbide Corporation (UCC) was sued by the Government of India ${ }^{82}$ In 1988, the Madhya Pradesh High Court upheld a district court's ruling that lifted the corporate veil of Union Carbide India Limited (UCIL) and held UCC liable for the operations of UCIL and for the mass disaster. ${ }^{83}$ The court found, inter alia, that UCC held more than one-half of the voting power of UCIL, empowering it not only to elect the board of directors but to control the management. It thus concluded that UCC "had real control over the enterprise which was engaged in carrying on the particular hazardous and inherently dangerous industry at the Bhopal plant and as such [UCC] was absolutely liable (without exceptions) to pay damages/compensation to the multitude of gas victims"'. ${ }^{84}$ In 1989, UCC welcomed and acted on the Supreme Court of India's directive to pay US $\$ 470$ million in compensation. ${ }^{85}$ There were, of course, several petitions filed with the Indian Supreme Court to challenge the settlement, which many viewed as a pittance, considering the enormity of the tragedy. ${ }^{86}$ In June 2010, seven UCIL former local employees, including the former UCIL chairman, were prosecuted and convicted in the District Court of Bhopal, India, of criminal negligence and sentenced to two years imprisonment and a fine of US $\$ 2,000$ each, the maximum punishment allowed by Indian law. However, the sentence imposed on the accused has been slammed as being too lenient. ${ }^{87}$ Warren Anderson, the CEO of UCC, was also charged with manslaughter (culpable homicide) by Indian authorities. Formal requests issued for his extradition were declined by the US authorities, citing a lack of evidence. ${ }^{88}$

Clearly, the various frameworks have helped to introduce environmental and human rights issues into corporate culture. They have led to the proliferation of a wide

81 US District Court, Southern District Texas, In Re: Oil Spill by the Oil Rig "Deepwater Horizon" in the Gulf of Mexico on April 20, 2010, MDL No. 2185; US District Court Eastern District of Louisiana, In Re: Oil Spill by the Oil Rig "Deepwater Horizon" in the Gulf of Mexico on April 20, 2010, MDL No. 2179; See also Stephanie Theodotou, 'Corporate Liability and Compensation Following the Deepwater Horizon Oil Spill: Is There a Need for an International Regime?' (2018) 6(1) Groningen Journal of International Law 161; Campbell Robertson and Clifford Krauss, 'BP May Be Fined Up to \$18 Billion for Spill in Gulf', The New York Times (New York, 4 September 2014) $<$ http://www.nytimes.com/2014/09/05/business/bp-negligent-in-2010-oil-spill-us-judge-

rules.html?_r=0> accessed 10 June 2019; Margaret Cronin Fisk, Lauren Brubaker Calkins and Jef Feeley, 'Worst Case: BP Ruling on Gulf Spill Means Billions More in Penalties', (Bloomberg LLP, 4 September 2014) <http://www.bloomberg.com/news/articles/2014-09-04/bp-found-grossly-negligentin-2010-gulf-of-mexico-spill> accessed 7 June 2020; Rachel Clingman, 'Liability Issues Surrounding the Gulf Coast Oil Disaster', A testimony before the Committee on the Judiciary, United States House of Representatives (27 May 2010).

82 Trotter and others (n 40); Eckerman (n 40); Peter Muchlinski, 'Group Liability and the Multinational Enterprise' (Paper presented at the University of Warwick Workshop on Corporate Control and Accountability, 30 June - 2 July 1991).

83 Union Carbide Corp v Union of India, No 26/88 at 91, Madhya Pradesh HC (4 April 1988).

84 Tim Covell, 'The Bhopal Disaster Litigation: It's Not over Yet' (1991) 16(2) North Carolina Journal of International Law and Commercial Regulation 279, 287.

85 Union Carbide Corporation v Union of India (1989) SCC (2) 540; see also Covell (n 84); Eckerman (n 40); Muchlinski (n 82).

86 See Covell (n 84).

87 BBC, 'Bhopal trial: Eight convicted over India gas disaster' (BBC News, 7 June 2010) <http://news.bbc.co.uk/2/hi/south_asia/8725140.stm> accessed 20 June 2019.

88 John V Vilanilam, Public relations in India: new tasks and responsibilities (SAGE 2011). 
range of private sector and market-driven initiatives to promote corporate social responsibility (CSR) ${ }^{89}$ It has been reported that a growing number of corporations are not only formulating but also implementing specific environmental and human rights policies. ${ }^{90}$ The Business and Human Rights Resource Centre asserts that over 240 enterprises have formulated their own guidelines, and more than 5200 corporations are listed as active members of the UN Global Compact. ${ }^{91}$ Following the emergence of the MNCs accountability frameworks, a new category of 'ethical investment' seems to have gained momentum, 'leading stockbrokers and shareholding funds to scrutinize the business practices of companies in their portfolios. ${ }^{92}$ Besides, many CSR-oriented indexes have emerged, including the Financial Times 'FTSE4Good' programme, which was launched in 2001 and measures the performance of companies that meet globallyrecognised corporate responsibility standards, and facilitates investment in those companies ${ }^{93}$ Such campaigns can go a long way to induce MNCs to behave in an ethical manner, as environmental and human rights abuses can be costly for them (MNCs) in terms of attracting and/or retaining customers, employees, and other stakeholders. ${ }^{94}$ Thus, ' $[\mathrm{t}]$ ried in the court of public opinion, they can suffer considerable reputational and financial damage through strikes and boycotts as well as loss of investor and consumer confidence. ${ }^{95}$

Today, the Global Compact 'counts more than 10,000 participants from over 130 countries, making it the largest non-binding corporate responsibility initiative worldwide'; $; 6$ and companies are encouraged to submit an annual report on the implementation of the framework's ten principles. Even though such reports are not subject to any review mechanism and have consequently been labelled a mere public relations exercise, no one can discredit the policy's contribution to discouraging MNCs from violating acceptable standards. ${ }^{97}$ It appears that the MNCs accountability frameworks that have been more successful, particularly in developed countries, are those at the local or national level. As a matter of fact, most of the international MNCs accountability instruments rely on domestic implementation and enforcement mechanisms. This role was most clearly expressed in the Charter of Economic Rights and Duties of States (CERDS) of 1974; ${ }^{98}$ and as Bunn agrees, 'the adoption, implementation, and enforcement of laws at the national level will remain paramount in governing corporate behaviour. ${ }^{199}$ It is evident from the discussion so far that some of the existing frameworks have been quite effective in getting corporations to operate and behave in an ethical manner, and holding them accountable for environmental and human rightsrelated misconducts.

\section{B. The Weaknesses/Failures of Regulatory Frameworks}

89 Bunn (n 16) 1287.

90 Silverman and Orsatti (n 9).

91 ibid.

92 Bunn (n 16) 1289-1290.

93 ibid.

94 See Picciotto (n 26).

95 Wouters and Chané (n 10) 21.

96 ibid 19.

97 ibid.

98 Charter of Economic Rights and Duties of States (adopted 12 December 1974) UNGA Res 3281 (XXIX).

99 Bunn (n 16) 1293-1294. 
Despite the important successes achieved by the existing accountability frameworks, there are enough evidence and data that demonstrate that their efficacy is far from satisfactory. A 2013 study by Aaronson and Higham shows little impact of the existing frameworks, including the Guiding Principles, on corporate practices so far. ${ }^{100}$ One key challenge in effectively regulating the operations of MNCs and holding them accountable for human rights violations and environmental damage is the fact that there is no binding international law under which a multinational corporation can be formed and have legal existence in various nation-states. ${ }^{101} \mathrm{As} \mathrm{Hu}$ observes, even the European Union, 'arguably the most integrated group of nations in the world, has so far, after many years of discussion, failed to agree on the legal basis for a European company'. ${ }^{102}$ Thus, existing international human rights law and international environmental law, as Augenstein and others note, generally do not directly impose obligations on MNCs to protect human rights and the environment. ${ }^{103}$ This, obviously, is due to the difficulty in ascribing international legal personality to them. ${ }^{104}$ At present, corporations, including subsidiary companies, can only be formed under domestic law, and thus acquire the nationality or domicile of the host State or the country under whose law they are incorporated. ${ }^{105}$ But the major problem here is succinctly expressed by $\mathrm{Hu}$ in these words:

The separate legal personality of the parent and its subsidiaries means that the parent is not automatically held liable for its subsidiary's liabilities. The concept of limited liability applies to any shareholder, whether that refers to a private individual or a parent corporation. This means that the global enterprise is able to hide behind the legal principles of separate legal personality and limited liability to avoid taking responsibility for the actions of a subsidiary that it owns and controls. ${ }^{106}$

The Bhopal disaster case lends credence to Hu's observation. Between 1986 and 2016, victims of the disaster and affected families who believe justice has not been served, on multiple occasions, brought class action lawsuits against UCC (which held 50.9 per cent shares of UCIL) in the US courts under the ATS. ${ }^{107}$ The claimants argued and demonstrated on each occasion that UCC designed the Bhopal plant, and was intimately and actively involved in every aspect of the building or installation process and management of the waste disposal systems that caused the pollution. It was therefore partly, if not fully, liable for the 1984 tragedy and the water pollution that the company's chemical plant continues to cause in the community. ${ }^{108}$ But UCC contested that argument, insisting that it had no role in operating the plant at the time of the disaster as the factory was owned, operated, and managed by UCIL, a separate entity. ${ }^{109}$ Claims

100 Aaronson and Higham (n 67).

$101 \mathrm{Hu}(\mathrm{n} \mathrm{14)}$.

102 ibid 115; See also Zerk (n 80).

103 Augenstein and others (n 9); See also Antonio Cassese, International Law in a Divided World (OUP 1986).

104 Silverman and Orsatti (n 9); Wouters and Chané (n 10).

$105 \mathrm{Hu}$ (n 14); Muchlinski (n 82).

$106 \mathrm{Hu}(\mathrm{n} \mathrm{14)} 115$.

107 Covell (n 84).

108 Narayan Lakshman, 'U.S. court rules in favour of Union Carbide' The Hindu (Chennai, 31 July 2014) $<$ https://www.thehindu.com/news/international/U.S.-court-rules-in-favour-of-UnionCarbide/article11181105.ece> accessed 20 July 2020.

109 The Associated Press, 'Company Defends Chief in Bhopal Disaster', The New York Times (New York, 2 August 2009) <https://www.nytimes.com/2009/08/03/business/global/03bhopal.html?r=1\&html> accessed 20 July 2020; Prasenjit Bhattacharya, 'Court Rules Union Carbide Not Liable in Bhopal Case' The Wall Street Journal (New $\quad$ York, 28 June 2012 ) 
filed with US courts were persistently dismissed and/or redirected to Indian courts on the grounds that UCIL was a standalone entity of India, and that UCC is not liable for the disaster. In 2016, the US Court of Appeals, in Sahu et al v UCC (also known as Sahu II), upheld an earlier decision of a district court that UCC was not liable for any plant site pollution effects arising out of the Bhopal tragedy. ${ }^{110}$

Rights and duties are two sides of the same coin, ${ }^{111}$ but despite the fact that multinational corporations enjoy substantial amount of rights, they do not seem to have any binding obligations at the international level, ${ }^{112}$ making it extremely difficult to hold them responsible and accountable for any involvement that they may have in environmental degradations and human rights violations. ${ }^{113}$ It has, for instance, been established that since 1995, over 370 bilateral and multilateral trade agreements have been signed and over 1,500 bilateral investment treaties have been concluded, involving almost all of the world's major economies. ${ }^{114}$ It has also been noted that under the European Convention of Human Rights (ECHR), companies enjoy a right to a fair and public hearing by an independent and impartial tribunal, access to a court, equality of arms, and reasonable length of the proceedings, among others. ${ }^{115}$ But unfortunately, these instruments and agreements, as Silverman and Orsatti note, 'confer supra-national rights on corporations, without granting corresponding rights to the people who may be adversely affected by their actions.' ${ }^{116}$

As MNCs incur no direct legal obligations under international human rights law, no concrete enforcement mechanism under international law exists. The relevant existing international frameworks, therefore, often require States themselves to regulate and monitor corporate activities harmful to human rights and the environment, and to enforce these regulations in case of corporate violations. ${ }^{117}$ But since MNCs operate beyond State boundaries, State regulation of their activities is usually inadequate. This inadequacy is made worse by the fact that there appears to be no consensus on the concept of corporate nationality (i.e. whether by place of registration, by the location of its headquarters, or by the place of origin of its founders).

Indeed, one of the corollaries of the expansion of MNCs, and of globalisation 'is that assertions of extraterritorial jurisdiction in private law cases, also referred to as "civil cases," are now commonplace'. ${ }^{118}$ The presence of complex cross-border networks of multinational corporate groups makes it necessary and reasonable for courts to

<https://www.wsj.com/articles/SB10001424052702303561504577493642502980690> accessed 20 July 2020.

110 Jagarnath Sahu et al v UCC and Madhya Pradesh State No. 07 Civ. 2156 (JFK), (30 July 2014).

${ }^{111}$ Nick Mabey, 'Defending the Legacy of Rio: The Civil Society Campaign against the MAI' in Sol Picciotto and Ruth Mayne (eds) Regulating International Business: Beyond Liberalization (Macmillan 1999) 60.

112 See Cassese (n 103); José E Alvarez, 'Are Corporations “Subjects" of International Law?' (2011) 9 Santa Clara Journal of International Law 1; Muchlinski (n 7).

${ }^{113}$ Lori F Damrosch, Louis Henkin, Richard Crawford Pugh, Oscar Schachter and Hans Smit, International Law: Cases and Materials (West Academic Publishing 2001); see also Silverman and Orsatti (n 9).

114 Rudolph Adlung and Martin Molinuevo, Bilateralism in Services Trade: Is There Fire Behind the (BIT) Smoke? (World Trade Organization 2008); see also Silverman and Orsatti (n 9).

115 Sovtransavto Holding v Ukraine App no 48553/99 (ECtHR, 25 July 2002) 95; Silvester's Horeca Service v Belgium App no 47650/99 (ECtHR, 4 March 2004); see also Wouters and Chané (n 10).

116 Silverman and Orsatti (n 9).

117 Augenstein and others ( $\mathrm{n} 9$ ).

118 Zerk (n 80) 144-145. 
occasionally 'take jurisdiction over foreign parties, or foreign activities or both, in order to hear and determine a case." 119 Thus, courts may assert extraterritorial jurisdiction directly over the foreign conduct of corporations, provided certain criteria are satisfied. But, as Zerk points out, the 'challenge for domestic legal systems, is to manage this in a way: (a) that is fair to the parties; and (b) that takes proper account of the sovereign interests of other states. ${ }^{, 20}$ It is worth mentioning that the rules or principles governing the use of civil jurisdiction are derived from domestic law; and each State usually acts unilaterally in developing these rules. ${ }^{121}$ This makes the exercise of extraterritorial civil jurisdiction by individual States very complex and cumbersome. MNCs accused of misconducts and dragged to the courts have often employed the ostensibly sacrosanct forum non conveniens doctrine to evade accountability or sanctions.

Interestingly, it appears that, with the sole exception of $\mathrm{Doe}^{122}$ and $\mathrm{Wiwa}^{123}$ (where out-of-court settlements were secured), all the lawsuits that have been filed against MNCs by 'alien' claimants under the ATS since 1992, have been unsuccessful. Baue asserts that, between 1993 and 2006, NGOs such as the International Labour Rights Fund, the Centre for Constitutional Rights, and EarthRights International filed 36 lawsuits against multinational companies under the ATS in US district courts, alleging corporate complicity in human rights abuse and other offences. But disappointingly, to date, not a single company has been found guilty under the ATS. He notes that of the 36 cases presented, 20 were dismissed. ${ }^{124}$ Silverman and Orsatti explain that 'some of those cases were dismissed on the grounds that the crimes committed did not fall within the scope of the law (which only applies to violations of "specific, universal and obligatory" norms such as those against torture, genocide, crimes against humanity, and summary executions)'. ${ }^{125}$

One notable case that has been dragging on for over two decades is Esther Kiobel v Royal Dutch Petroleum/Shell, ${ }^{126}$ which was initiated at a US district court and is currently being dealt with at the Court of the Hague. ${ }^{127}$ In this case, Esther Kiobel and 11 other individuals filed a class action lawsuit with a US district court under the ATS, accusing the Royal Dutch Petroleum/Shell, and SPDC, of being complicit in gross violation of fundamental human rights. The claimants allege that their lawful protests and campaigns against the environmental damage caused by oil extraction in their region were violently suppressed by agents of the Nigerian government, either in conspiracy with the SPDC and its affiliated businesses, or at the SPDC's own behest. They also accuse the defendants of causing the destruction of their property, forcing them to flee Nigeria for their lives, and subjecting their family members to arbitrary arrest and detention, torture and extrajudicial killings. One of the core legal questions that the US courts had to address in this case was whether, and under what circumstances, the ATS provides jurisdiction over claims brought against corporations for violations that occurred on foreign sovereign territory. The Court of Appeals for the Second Circuit, on September 17, 2010, upheld the District Court for the Southern District of New York's earlier

\footnotetext{
119 ibid.

120 ibid 145.

121 ibid.

${ }^{122}$ Doe (n 72).

123 Wiwa (n 38).

124 Bill Baue, 'Win or Lose in Court' (2006) Business Ethics, Summer; see also Silverman and Orsatti (n 9).

${ }^{125}$ Silverman and Orsatti (n 9).

${ }^{126}$ Esther Kiobel v Royal Dutch/Shell 621 F3d 111 (2d Cir 2010); Esther Kiobel v Royal Dutch Petroleum Co, 133 SCt 1659 (2013).

${ }^{127}$ Esther Kiobel v Royal Dutch Shell Plc (Court of Justice of the Hague) [2019] ECLI:NL:RBDHA: 2019:4233.
} 


\section{Environmental Degradation and Human Rights Violation: A Cursory Overview of the Potential of the Existing Frameworks to Hold Multinational Corporations}

dismissal of the claim, stating that the ATS does not provide jurisdiction over claims for violations of international law committed by corporations and not individual persons. ${ }^{128}$ In June 2011, the claimants filed a petition of certiorari with the US Supreme Court; but in April 2013, the Supreme Court held that the ATS has no extraterritorial application. It reasoned that

$[\mathrm{N}]$ othing in the text of the statute suggests that Congress intended causes of action recognized under it to have extraterritorial reach. The ATS covers actions by aliens for violations of the law of nations, but that does not imply extraterritorial reach - such violations affecting aliens can occur either within or outside the United States. Nor does the fact that the text reaches "any civil action" suggest application to torts committed abroad; it is well established that generic terms like "any" or "every" do not rebut the presumption against extraterritoriality. ${ }^{129}$

The Court further explained that claims about conducts that occurred outside the US filed under the ATS must 'touch and concern the territory of the United States ... with sufficient force to displace the presumption against extraterritorial application.' ${ }^{130}$ Applying this standard to the facts of the Kiobel case, the Court dismissed the claims against Royal Dutch/Shell. Thus, the alleged misconduct of the defendants (who are foreign corporations) occurred outside the US, but the defendants 'mere corporate presence' in the US, in the court's reasoning, did not sufficiently 'touch and concern' the territory of the US to displace the presumption against extraterritoriality. ${ }^{131}$ Evidently, the court's formulation, as Justices Alito and Thomas admit, 'leaves much unanswered.' ${ }^{132}$ Thus, the pronouncement is pretty vague, as it provides little guidance about the meanings of phrases such as, 'touch and concern' and 'sufficient force'. Justice Breyer proposes three conditions or circumstances under which the ATS may justifiably be invoked. He states: 'I would find jurisdiction under this statute where (1) the alleged tort occurs on American soil, (2) the defendant is an American national, or (3) the defendant's conduct substantially and adversely affects an important American national interest'. ${ }^{133}$ Unfortunately, this attempt at clarifying the court's controversial pronouncement has been far from helpful, as the third condition raises more questions than it answers. Therefore, these and other similar questions that arise from the judgement must, as Hoffman notes, await further consideration. ${ }^{134}$

There is no doubt that the US Supreme Court's decision in Kiobel does not represent an unequivocal ban on all extraterritorial applications of the ATS as some have

${ }^{128}$ Kiobel (n 126) - The suit alleges that Shell, through its Nigerian subsidiary Shell Petroleum Development Company of Nigeria (SPDC), provided transport to Nigerian troops, allowed company property to be used as staging areas for attacks against the Ogoni and provided food to the soldiers and paid them. The plaintiffs claimed the defendant companies were complicit in the commission of torture, extrajudicial killing and other violations pursuant to the Alien Tort Claims Act (ATCA).

129 ibid para III; see also Julia Zebley, 'Supreme Court Rules against Extraterritorial Application of Alien Tort Statute' (Jurist, 17 April 2013) <https://www.jurist.org/news/2013/04/supreme-court-rulesagainst-extraterritorial-application-of-alien-tort-statute $>$ accessed 20 August 2020.

130 Kiobel (n 126).

131 ibid.

132 ibid [1670] (Alito J).

133 ibid [1671] (Breyer J).

134 Paul L Hoffman, 'Kiobel v Royal Dutch Petroleum Co.: First Impressions', (2013) 52(28) Columbia Journal of Transnational Law 28. 
suggested. ${ }^{135}$ However, it makes its use by prospective foreign claimants exceedingly and implausibly difficult. Even though the Court stressed that the presumption against a statute's applicability to extraterritorial conduct governed the ATS, it did not rule out the possibility 'that some tort claims arising under the law of nations could displace that presumption, so long as those claims "touch and concern the territory of the United States" with "sufficient force." 136 Thus, in the view of the Court, for a claim to be sufficient to displace that presumption, it would have to do more than merely 'touch and concern' the territory of the US. The problem, however, is that the Court did not formulate any test for determining whether or not a claim's connection with the territory of the US has 'sufficient force'. In fact, Justice Kennedy emphasised the possibility of some claims displacing the presumption against extraterritoriality in his concurring opinion. ${ }^{137}$ Corbett argues that ' $[\mathrm{h}] \mathrm{ad}$ the Court intended to foreclose foreign-conduct human rights litigation, it could have done so more clearly'. ${ }^{138}$ Thus, the fact that the Court carefully chose vocabulary or phrases such as 'touch and concern' and 'sufficient force' discredits any view that 'Kiobel represents an absolute bar to suits for international law violations committed in the territory of a foreign sovereign, even if some preparatory conduct occurred in the United States'. ${ }^{139}$

The decision in Kiobel brought an unceremonious, almost automatic, end to Sarei $v$ Rio Tinto. ${ }^{140}$ In the Sarei case, the residents of the island of Bougainville in Papua New Guinea filed a class action lawsuit with a US court against Rio Tinto (a British mining corporation operating in about 40 countries) under the ATS in 2000, alleging various human rights violations and environmental extirpation caused directly or indirectly by Rio Tinto. After a long legal battle, the US appeals court, on 28 June 2013, dismissed the case, citing the Supreme Court's reasoning (concerning extraterritorial application of the ATS) in Kiobel. ${ }^{141}$ Indeed, the decision that the ATS could not be used to sue corporations for violations of international law dealt a substantial blow to international law and its undertaking to protect fundamental human rights.

Traditionally, the courts of common law countries, such as the UK, have been very cautious about handling claims against a foreign party (foreign entity) as such proceedings come with a heavy price and may also interfere with the sovereignty of the country where the trial should ordinarily have taken place. ${ }^{142}$ In the UK, the Civil Procedure Rules, ${ }^{143}$ and the Supreme Court's (previously, the House of Lords) decision in Seaconsar Far East Ltd v Bank Markazi Jomhouri Islami Iran ${ }^{144}$ suggest that permission for commencement of proceedings against a foreign party (commonly known as service out of the jurisdiction) will be granted by the courts only if the claimant convinces the courts that the issue to be tried is exceptionally serious and that the UK courts are the most

135 Christopher A Whytock, Donald E Childress, Michael D Ramsey, 'Foreword: After Kiobel International Human Rights Litigation in State Courts and Under State Law' (2013) 3(1) UC Irvine Law Review 1; Paul Hoffman and Beth Stephens, 'International Human Rights Cases Under State Law and In State Courts' (2013) 3(1) UC Irvine Law Review 9; Roger P Alford, 'The Future of Human Rights Litigation After Kiobel' (2014) 89 Notre Dame Law Review 1749.

136 Ross J Corbett, 'Kiobel, Bauman, and the Presumption Against the ExtraTerritorial Application of the Alien Tort Statute' (2015) 13(1) Northwestern Journal of Human Rights 50.

137 Kiobel (n 126) at [1669] (Kennedy J) and at [1673] (Breyer J).

138 Corbett (n 136) 56.

139 ibid.

140 Alexis HolyweekSarei et al v Rio Tinto Plc, 9th US Circuit Court of Appeals, No. 02-56256 (2011).

141 See Jonathan Stempel, 'Rio Tinto wins end to human rights abuse lawsuit in US' (Reuters , 29 Jun 2013).

142 See Zerk (n 80).

143 The UK Civil Procedure Rules, CPR 6.20 and 6.21.

144 Seaconsar Far East Ltd. v Bank Markazi Jomhouri Islami Iran [1994] 1 AC 438 (HL). 


\section{Environmental Degradation and Human Rights Violation: A Cursory Overview of the Potential of the Existing Frameworks to Hold Multinational Corporations}

appropriate forum for determining the matter. ${ }^{145}$ However, the discretion of the UK courts to accept or refuse to take jurisdiction over litigations concerning foreign parties has, undergone a quasi-alteration pursuant to the Brussels Regulation, ${ }^{146}$ as evident in Owusu $v$ Jackson. ${ }^{147}$ Zerk succinctly summarises the relevant portion of the pronouncement of the European Court of Justice (ECJ) as follows:

Now, where the defendant is resident in another EU member state and the matter falls within the scope of the one or more of the Brussels regime jurisdictional rules, service of process on that party is a matter of right and is not up to the court's discretion. The Brussels regime also removes the ability of the UK courts to decline jurisdiction on the basis of forum non conveniens where one of the defendants is domiciled in the UK, even where the alternate jurisdiction is not a state party to the Brussels regime. ${ }^{148}$

There is no question that the ECJ's ruling in Owusu significantly influenced the UK courts' decision to grant permission for the claims against the Trafigura group, and Vedanta Resources and its Zambian subsidiary to be tried in the UK. ${ }^{149}$ For instance, in the Vedanta appeal case, ${ }^{150}$ the Supreme Court accepted jurisdiction on the grounds that Vedanta was incorporated and domiciled in the United Kingdom and therefore Article 4 of the Recast Brussels Regulation was applicable; that the claimants' pleaded case and supporting evidence disclose real triable issue against Vedanta; and that even though it did not believe that The United Kingdom was the ideal place wherein the claim should be brought, it was convinced that there was a real risk that the claimants would not obtain access to substantial justice in the Zambian jurisdiction (both in the High Court and in the Court of Appeal). ${ }^{151}$ In Okpabi v Royal Dutch Shell (where the issues addressed are strikingly similar to those of Vedanta), a further question that needed clarification was raised - the question of whether even if the courts accepted jurisdiction, the cause of action asserted would have a real prospect of success or whether there was any real issue to be tried in the first place. The Court of Appeal appeared to have based their decision on a principle that a parent company could never incur a duty of care in respect of the activities of a subsidiary by maintaining group-wide policies and guidelines; but the Supreme Court disagreed. After critically considering the pleaded case, the Court decided that it disclosed an arguable claim, and consequently allowed the appeal. ${ }^{152}$ It, however,

145 ibid; CPR (n 143).

146 Council Regulation (EC) No 44/2001 on jurisdiction and the recognition and enforcement of judgments in civil and commercial matters ('Brussels Regulation'), 22 December 2000.

147 C-281/02 Andrew Owusu v Jackson et al [2005] ECR I-01383; European Court of Justice (Grand Chamber) ruled that proceedings may not be stayed by UK courts on the basis of forum non conveniens where at least one of the defendants is domiciled in the UK, as this would be inconsistent with the stipulations of the Brussels Regulation.

148 Zerk (n 80) 149.

149 Owusu (n 147); Vedanta Resources PLC and another (Appellants) v Lungowe and others (Respondents) [2019] UKSC 20; This case concerns approximately 1,826 poor Zambian citizens who live in rural farming communities and are reliant on open bodies of water for drinking and irrigation for their crops. They allege that their health and farming activities have been damaged as a result of the defendants/appellants' (Vedanta and its subsidiary, KCM) discharge of toxic matter from a mine KCM was operating into those waterways from 2005 onwards.

150 Vedanta (n 149).

151 ibid.

152 Okpabi and others (Appellants) v Royal Dutch Shell Plc and another (Respondents) [2021] UKSC 3. 
needs to be emphasised that the Regulation's scope of application, as Croser and others observe, is limited to European defendants. Consequently, 'residual jurisdiction over non-EU entities, including foreign subsidiaries of European companies, will be determined by domestic private international law rules of the forum'. ${ }^{153}$

Many giant corporations continue to damage the environment and abuse human rights despite the existence of international and domestic regulatory frameworks. Various groups and individual activists have exposed child labour, wage exploitation, and other unimaginable forms of maltreatment of workers in a number of the Bangladesh factories that serve as the major clothing suppliers of Tesco, Asda, and Primark in the UK. ${ }^{154}$ It was reported that wages were as low as 3 pence per hour, with workers often working more than 80 hours a week. ${ }^{155}$ But unfortunately, the existing frameworks such as the Norms and the Guiding Principles which recognise 'the importance of holding parent companies and their subsidiaries, contractors, and agents liable for violations of human rights', ${ }^{156}$ have not been efficacious enough to prevent these big organisations and their suppliers from engaging in such serious abuse, or to hold them accountable for the violations. ${ }^{157}$ Some analysts have also raised concerns about the failure of the relevant international mechanisms to establish a clear normative framework as a reference point against which the human rights performance of companies can be measured. ${ }^{158}$ Besides, very few of the frameworks provide for a clear and effective implementation and complaints mechanisms. ${ }^{159}$ It has also been asserted that 'while the ILO has developed a vast range of conventions, the level of ratification is often low', and concerns have been raised 'about the limited number of enforcement actions.' 160

Although the adoption, implementation, and enforcement of frameworks at the national level remain paramount in governing corporate behaviour and holding MNCs liable for environmental defilement and human rights violations in host States, there are certain inescapable fundamental challenges that are faced when seeking remedies for environmental and human rights violations aided or abetted by MNCs in host States through domestic mechanisms. Among them are, corruption, 'a lack of legal remedies in host country jurisdictions with lax national laws, inefficient justice systems, lack of political will to prosecute investors, [and/] or a combination of these obstacles. ${ }^{161}$

For instance, the Ivorian domestic mechanism's failure to satisfactorily address the Probo Koala disaster has been blamed on endemic corruption within both government and

${ }^{153}$ Marilyn Croser, Martyn Day, Mariëtte Van Huijstee and Channa Samkalden, 'Developments in the Field Vedanta v Lungowe and Kiobel v Shell: The Implications for Parent Company Accountability' (2020) 5 Business and Human Rights Journal 130, 131.

154 Faisal Islam, 'Child labour making Tesco clothes' (Channel 4 News, 10 October 2006) <http://web.archive.org/web/20061026184624/http://www.channel4.com/news/specialreports/special-reports-storypage.jsp?id=3554> accessed 10 June 2020; Martin Hickman, 'The real price of cheap clothes: Bangladeshi sweatshop labourers paid just $3 \mathrm{p}$ an hour' The Independent (London, 8 December 2006) <http://www.independent.co.uk/news/uk/this-britain/the-real-price-of-cheapclothes-bangladeshi-sweatshop-labourers-paid-just-3p-an-hour-427589.html> accessed 10 June 2020.

155 ibid.

156 Vega and others (n 46).

157 Islam (n 154); Hickman (n 154).

158 Rory Sullivan and Nicolas Hachez, 'Human Rights Norms for Business: The Missing Piece of the Ruggie Jigsaw - The Case of Institutional Investors' in Radu Mares (ed), The UN Guiding Principles on Business and Human Rights: Foundations and Implementation (Martinus Nijhoff 2012).

159 See Picciotto (n 26).

160 Bunn (n 16) 1277; See also Steven R Ratner, 'Corporations and Human Rights: A Theory of Legal Responsibility' (2001) 111 Yale Law Journal 443; Virginia A Leary, 'Lessons from the Experience of the International Labour Organisation' in Philip Alston (ed), The United Nations and Human Rights: A Critical Appraisal (Clarendon 1992).

161 Silverman and Orsatti (n 9) 32. 
the judiciary. ${ }^{162}$ Thus, even though it has been indicated that some successes were achieved abroad ${ }^{163}$ the handling of the case at the domestic level was very disappointing. Following investigations conducted by a National Commission of Enquiry and the State Prosecutor, a number of private actors and public officials, mostly local folks, were charged in connection with offences relating to the toxic waste dumping. These included: WAIBS' director, Tommy's manager, and Puma Energy's manager, as well as JeanPierre Valentini (Trafigura's manager for Africa) and Claude Dauphin (Trafigura's CEO) who were both arrested at Abidjan airport as they were leaving the country following a visit to establish the facts of the incident. But to the utter disappointment of many locals, in February 2007, the charges against Dauphin, Valentini, and Puma's director were dropped, citing lack of evidence, and they were released. Of the other individuals who were indicted, only a handful were convicted, the only significant one being Tommy's director who was sentenced to 20 years' imprisonment. ${ }^{164}$ Prior to the release of Dauphin and Valentini, the Ivorian government entered into a settlement agreement with the Trafigura Group without consulting relevant stakeholders. Under this non-transparent and dubious agreement, the government received approximately US $\$ 200$ million as compensation to the State and the victims, and to pay for clean-up of the toxic waste. Unfortunately, the nature of the settlement created huge obstacles to the victims' pursuit of real justice and remedy, as it required, among others, that on-going prosecutions against Trafigura parties be discontinued. It also limited the rights of the victims to seek compensation in Ivorian courts. Consequently, victims of the pollution had no other option than to attempt to seek proper legal redress in other jurisdictions such as the Netherlands, UK and France. ${ }^{165}$

The problem of lax national laws is also a major reason why UCC, UCIL and key officers of the corporation never faced real justice. It has been suggested that exemplary and punitive damages were rarely allowed in Indian lawsuits at the time of the Bhopal disaster; and wrongful death judgments often amount to a few rupees. ${ }^{166}$ It has been indicated that each of the victims of the Bhopal disaster received no more than 25,000 rupees (US\$350) compensation. ${ }^{167}$ Because punitive damages apparently did not exist in Indian lawsuits, UCC, UCIL and key officers got away with manslaughter. As Trotter and other observe, the only reason UCC got away with manslaughter was because the tragedy occurred in India, and not any of the developed countries where more effective, relevant legal mechanisms exist. ${ }^{168}$ It has also been indicated that many governments or political regimes, particularly those in developing countries, are in bed with MNCs who

${ }^{162}$ Amnesty International and Greenpeace (n 80); In fact, there were several companies involved in this case, namely: Trafigura Beheer BV (the parent company based in the Netherlands), Trafigura Ltd (its English subsidiary that chartered the ship), Puma Energy (Trafigura Beheer BV's subsidiary in Ivory Coast), Compagnie Tommy (a local firm eventually contracted for the waste disposal) and WAIBS Shipping (Puma Energy's agent engaged to supervise the reception of the waste and the disposal operations).

163 ibid.

164 ibid.

165 ibid

166 Trotter and others (n 40).

167 ibid; Satinath Sarangi, 'Bhopal Disaster: Judiciary's Failure' (1995) 30(46) Economic and Political Weekly 2907.

168 Trotter and others (n 40); Covell (n 84); Adam Withnall 'Bhopal gas leak: 30 years later and after nearly 600,000 were poisoned, victims still wait for justice' The Independent (London, 14 February 2019) $<$ https://www.independent.co.uk/news/world/asia/bhopal-gas-leak-anniversary-poison-deathscompensation-union-carbide-dow-chemical-a8780126.html> accessed 18 July 2020. 
provide these corrupt regimes financial incentives, political campaign logistics and, in some cases, international credibility. ${ }^{169}$ This makes it enormously difficult for such governments to hold those MNCs accountable for breaches of relevant domestic legal instruments. This problem is reiterated by Croser and others who note that ' $[\mathrm{w}]$ hile host state courts often remain the preferred forum for pursuing legal redress, factors such as lack of due process, political interference, mistrust of the courts or absence of affordable legal assistance mean that a claim in the host state may be unviable'. ${ }^{170}$ It is, therefore, not surprising that in cases such as Doe, Wiwa, Sarei, Bowoto $v$ Chevron Corp, and several others, the complainants did not seek justice in their own domestic courts. ${ }^{171}$ The claimants possibly felt they would have a better chance of succeeding in a non-domestic legal forum than a domestic one.

Moreover, 'economically weaker states depend on the investments of MNCs and may be unwilling to enact and enforce demanding human rights and environmental standards in order to enhance their attractiveness to foreign investors' ${ }^{172}$ For example, the giant global mining company, Anglo-Gold Ashanti (owned by Anglo American plc) which operates in a number of countries, has been accused of relentlessly degrading the environment and abusing human rights in Ghana since its establishment. ${ }^{173}$ In January 2011, the company was unsurprisingly named the world's 'Most Irresponsible Company' at the Public Eye Awards, in Davos, Switzerland. ${ }^{174}$ Ghana has various environmental and human rights policies and other frameworks that are meant to regulate the activities of MNCs, particularly those in the mining sector, and hold them accountable for any environmental damage and human rights violations they cause in the country. Yet, corporations such as Anglo-Gold Ashanti continue to cause severe damage to the environment and to seriously violate human rights without any action taken against them by the State or the existing mechanisms. ${ }^{175}$ As one NGO, War on Want, observes, '[i]n Ghana and Mali, local communities ... suffer from fear and intimidation and from the damaging impact of its [(Anglo-Gold)] mines on their environment, health and livelihoods. In Ghana, mining operations have devastated the environment and polluted vital water resources.' ${ }^{176}$ Countless Anglo-Gold Ashanti underground workers are believed to have lost their lives, and many more continue to die each year as a direct

169 See Covell (n 84); Wouters and Chané (n 10).

170 Croser and others (n 153) 130.

171 Doe (n 72); Wiwa (n 38); Sarei (n 140); Bowoto v Chevron Corp, 481 F Supp 2d 1010 (N.D. Cal. 2007); Bowoto v Chevron Corp, 621 F.3d 1116 (9th Cir. 2010); see also Engobo Emeseh, 'Challenges to Enforcement of Criminal Liability for Environmental Damage in Developing Countries: With Particular Reference to the Bhopal Gas Leak Disaster' (2003) 1(5) Oil, Gas and Energy Law Intelligence 1.

172 Wouters and Chané (n 10) 4; See also Jan Wouters and Leen Chanet, 'Corporate Human Rights Responsibility: A European Perspective' (2008) 6 Northwestern Journal of International Human Rights 262.

173 ActionAid International, Gold Rush: The impact of gold mining on poor people in Obuasi, Ghana (Johannesburg: ActionAid

2006) <https://www.actionaid.org.uk/sites/default/files/doc_lib/gold_rush.pdf> accessed January 2020; War on Want, Anglo America: The Alternative Report (War on Want 2007).

174 Mail\&Guardian, 'AngloGold wins shame award at Davos' (Mail\&Guardian,29 January 2011) <http://mg.co.za/article/2011-01-29-anglogold-wins-shame-award-at-davos> accessed 12 January 2020; Colombia Solidarity Campaign, 'La Colosa: The Quest for Eldorado in Cajamarca, Columbia' (Colombia Solidarity Campaign, 4011 June <http://www.colombiasolidarity.org.uk/attachments/article/548/La\%20Colosa\%20Report\%204\%20J une\%202011.pdf $>$ accessed 12 January 2020.

175 ActionAid (n 173); War on Want (n 173) 6 - 7

176 War on Want 2 (n 173). 


\section{Environmental Degradation and Human Rights Violation: A Cursory Overview of the Potential of the Existing Frameworks to Hold Multinational Corporations}

Accountable

result of poor health and safety standards, ${ }^{177}$ yet the company has never been made to be accountable. Ironically, Obuasi-Ashanti, the place where over 80 per cent of the mining activity in the country occurs is one of the most deprived and poverty-stricken towns in Ghana. ${ }^{178}$

There are a few instances where victims of human rights abuse and environmental degradation by MNCs in developing countries have managed to drag those offending organisations to domestic courts and been awarded huge compensations. But frustratingly, the realistic enforcement of the judgements has not been possible. For instance, in Aguinda $v$ ChevronTexaco (hereinafter Lago Agrio), a group of Ecuadorians in 2003, filed a class-action lawsuit with a domestic court against Chevron-Texaco for allegedly polluting the Amazon by dumping 18 billion gallons of toxic waste during its operations there between the mid-1960s and $1992 .{ }^{179}$ This pollution, the plaintiffs alleged, was the cause of numerous diseases, 'cancer deaths, miscarriages, birth defects, dead livestock, sick fish, and the near-extinction of several tribes; Texaco's legacy in the region amounted to a "rain-forest Chernobyl." 180 In February 2011, the provincial court ruled that Chevron was responsible for the massive contamination and concomitant catastrophes, and ordered it to pay US\$18 billion dollars in damages - the largest judgment ever awarded in an environmental lawsuit. The decision was upheld by the Ecuadorian High Court in 2012 (although the compensation was reduced to US\$9.5bn) and then the Constitutional Court (the highest court in the country) in 2018. But to date, the relevant Ecuadorian authorities have not been able to enforce the judgement. In fact, by the time the case concluded, Chevron had emptied its bank accounts in Ecuador and transferred all of its assets, making it almost impossible for the domestic courts judgements to be enforced.

Chevron somehow managed to get an arbitration tribunal (Investor-State Dispute Settlement panel) to order the government of Ecuador in 2018 to ensure 'the immediate suspension of the enforceability of the Lago Agrio Judgment and the implementation of such other corrective measures as are necessary to "wipe out all the consequences" of the Respondent's internationally wrongful acts.' ${ }^{181}$ Chevron had argued in a claim (Chevron $v$ Ecuador) filed with the arbitration tribunal that the Ecuadorian courts delivered a procedurally flawed judgement and also violated a bilateral investment treaty when they declared Chevron liable for the contamination resulting from the company's oil and gas activities in the Lago Agrio case. ${ }^{182}$ It must be stressed that the tribunal, applying

177 The Sydney Morning Herald, 'AngloGold wants zero mine deaths by 2015' Sydney Morning Herald (Sydney, 29 March 2010) <http://news.smh.com.au/breaking-news-business/anglogold-wants-zeromine-deaths-by-2015-20100329-r7i2.html> accessed 7 January 2020.

178 ActionAid (n 173).

179 Maria Aguinda et al v ChevronTexaco Corp, Provincial Court of Justice of Sucumbios (Lago Agrio) Case No. 002-2003 (14 February 2011); The class-lawsuit was first filed with a US district court in 1993; but in 2001 the court dismissed the case on grounds of forum non conveniens. This decision was upheld in 2002 by the US Court of Appeals for the Second Circuit; See also Patrick Radden Keefe 'Reversal of Fortune: The Lago Agrio Litigation' (2013) 1(2) Stanford Journal of Complex Litigation 199.

180 Patrick Radden Keefe, 'Reversal of Fortune: The Lago Agrio Litigation' (2013) 1(2) Stanford Journal of Complex Litigation 199, 200. see also Steven R Donziger, 'Rainforest Chernobyl: Litigating Indigenous Rights and the Environment in Latin America' 2004 Human Rights Brief 1.

181 Chevron Corporation and Texaco Petroleum Corporation v Ecuador (II) (PCA Second Partial Award Tracking) [2018] IIC 1466 ix para 9.17; This case was in fact filed in 2009 to, among others, seek protection from liability in the Lago Agrio case; but it was amended following the provincial court's ruling in 2011.

182 ibid. 
international law, categorically mentions in its award that it 'does not consider that it has the power to annul the Lago Agrio Judgment as regards its lack of "correctness"". ${ }^{183}$ Hence, its pronouncement is not tantamount to a direct reversal of the decisions of the Ecuadorian domestic courts. However, the tribunal's decision to invite or ask the State to take all the available measures in order to revert or suspend the judgment, raises a number of questions regarding the extent of the powers of domestic courts in developing countries in dealing with giant multinational organisations.

One other major challenge in effectively regulating the activities of MNCs, as Emeseh explains, is lack of 'sufficient and adequately trained personnel to monitor corporate environmental practices and enforce the laws in the event of breach .... [Thus,] the institutions set up to monitor and implement the laws usually lack the necessary facilities as well as sufficient and adequately trained manpower to do so'. ${ }^{184}$ This problem is very pronounced, particularly, in developing countries. The Bhopal tragedy, for example, has been blamed largely on the ineffectiveness of the regulatory systems that existed at the time. They have been vehemently criticised for not doing enough to prevent the disaster from occurring, in the first place. ${ }^{185}$ As Trotter and others note, 'in essence, the operating environment in India, for various reasons, was woefully inadequate in terms of safety, land use, and environmental controls to prevent the disaster' ${ }^{186}$ In Nigeria, activists and experts have blamed the persistent pollution and degradation of the environment by MNCs on inefficient regulatory bodies and poor implementation of national environmental policies. ${ }^{187}$ The serious environmental and human rights infringements by MNCs in the Niger Delta region that set off Wiwa and Kiobel ${ }^{188}$ occurred largely due to the incompetence and ineffectiveness of relevant regulatory institutions in Nigeria.

It is obvious from the discussion and highlighted evidence that the existing MNCs regulatory and accountability frameworks are hugely inadequate to effectively curtail environmental degradation and human rights abuses. ${ }^{189}$ However, this article does not support Chesterman's view that the MNCs regulatory frameworks are an 'illusion' and may be 'worse than no regulation at all'. ${ }^{190}$ This is because although not all of the mechanisms profiled in this discussion have been equally effective in promoting the environmentally friendly practices and fundamental human rights principles that corporate entities are required to uphold, they have, to some appreciable extent, helped to raise awareness and to introduce environmental and human rights issues into corporate culture.

\section{The Way Forward}

There is no question that ensuring corporate accountability is an enormous challenge that cannot be satisfactorily achieved through non-binding international and regional 'legal' frameworks (soft law) alone. Besides, since MNCs operate beyond State boundaries, attempts to institute a domestic or home State model of extraterritorial regulation to make them accountable for human rights violations and environmental degradation will

\footnotetext{
183 ibid paras 9.14, 9.18.

184 Emeseh (n 171) 19.

185 Trotter and others (n 40).

186 ibid.

187 Ite and others (n 28).

188 Wiwa (n 38); Kiobel (n 126).

189 Adam Walczak, 'Coming to the Table: Why Corporations Should Advocate for Legal Norms for the Protection of Indigenous Rights' (2010) 42 The George Washington International Law Review 623.

190 Chesterman (n 11) 324.
} 


\section{Environmental Degradation and Human Rights Violation: A Cursory Overview of}

the Potential of the Existing Frameworks to Hold Multinational Corporations

always be inadequate. It is evident that individuals, particularly those in developing countries, adversely affected by MNCs' activities often have a low probability of attaining redress in their own country (i.e. the host country). This, as already noted, is due to a lack of political will, ineffective legislation, politicisation of the judiciary, lack of legal aid, poor infrastructure, and/or corruption among local authorities. To overcome the current regulatory problems faced and ensure that legal liability for the offences of MNCs and individuals acting on their behalf is well handled, the formulation of a comprehensive and legally binding international document (hard law) and the establishment of a global court for international corporate transgressions within the UN systems are vital. ${ }^{191}$

The Preamble of the Universal Declaration of Human Rights provides that every individual and every organ of society has an obligation to uphold and promote the principles contained in the Declaration. One would thus not be far from right in arguing, as Avery and others and Alvarez do, that the use of the word 'organ' suggests that the obligation also applies to entities such as companies. ${ }^{192}$ Indeed, since the last couple of decades, there have been growing calls for MNCs to be subjected to a set of rigid universal standards that will apply to companies above and beyond the demands of any specific region or locality, as well as calls for a systematic and comprehensive procedure for adjudicating corporate liability at the international level. ${ }^{193}$ For instance, in Urbaser $v$ Argentina, the Tribunal (International Centre for Settlement of Investment Disputes) made mention of the possibility of human rights obligations being incumbent on a foreign investor (i.e. an MNC) under both domestic and international law. ${ }^{194}$ In Burlington $v$ Republic of Ecuador, Burlington Resources Inc sued Ecuador, alleging that certain measures taken by the respondent, including the seizure of shares, the physical takeover of the production facilities and the termination of a contract constituted an expropriation. Ecuador denied the allegations and filed a counterclaim, alleging that the claimant breached contractual obligations and violated Ecuadorian environmental laws; besides, its activities in the country resulted in significant environmental harm. The Tribunal rendered a decision holding Burlington liable for environmental harm. ${ }^{195}$ Even though the investor's obligations were mainly found in domestic law, the Burlington ruling indicates the possibility of investor obligations being enforced through international proceedings.

191 Kevin T Jackson, 'A Cosmopolitan Court for Transnational Corporate Wrongdoing: Why Its Time Has Come' (1998) 17(7) Journal of Business Ethics 757.

192 Christopher Avery, Annabel Short, Gregory Tzeutschler Regaigno, 'Why all Companies should Address Human Rights-and how the Business \& Human Rights Resource Centre can help' in Judith Hennigfeld, Manfred Pohl and Nick Tolhurst (eds), The ICCA Handbook on Corporate Social Responsibility (John Wiley \& Sons 2012); Alvarez (n 112).

193 Jackson (n 191); See also Ronen Shamir, 'Between self-regulation and the Alien Tort Claims Act: on the contested concept of corporate social responsibility' (2004) 38(4) Law and Society Review 635, 637; Emeka Duruigbo, 'Corporate Accountability and Liability for International Human Rights Abuses: Recent Changes and Recurring Challenges' (2008) 6(2) Northwestern Journal of International Human Rights 222; Miguel Juan Taboada Calatayud, Jesús Campo Candelas and Patricia Pérez Fernández, 'The Accountability of Multinational Corporations for Human Rights' Violations' (2008) No. 64/65 Cuadernos Constitucionales de la Cátedra Fadrique Furió Ceriol 171; Luis Gallegos and Daniel Uribe, 'The Next Step against Corporate Impunity: A World Court on Business and Human Rights?' (2016) 57 Online Symposium 7; Stefanik (n 45).

194 Urbaser SA and Consorcio de Aguas Bilbao Bizkaia, Bilbao Biskaia Ur Partzuergoa v The Argentine Republic, (Award) ICSID Case No. ARB/07/26 (8 December 2016).

195 Burlington Resources Inc v Republic of Ecuador (Award) ICSID Case No. ARB/08/5 (18 October 2018). 
Admittedly, the notion of a binding global legal document and a world court for MNCs may seem too radical and enormous to contemplate, but as some commentators rightly mention, it remains an essential step towards preventing the violation of fundamental human rights and the degradation of the environment by MNCs, and guaranteeing victims' access to remedies for corporate wrongdoings. ${ }^{196}$ Thus, the high level of sophistication or complexity of MNCs' structures, operations and misconducts requires enhanced global coordination and cooperation.

\section{A. Binding International Legal Document}

To effectively regulate the operations of MNCs, obedience to or compliance with basic norms should not be left up to the voluntary good-will and discretion of these corporations many of which can be extremely powerful. Instead, there should be a codification of binding instruments for all MNCs. As Windsor observes, it is enormously difficult for corporations, particularly transnational businesses, to render ethical decisions or operate ethically in the absence of well-defined legal prescriptions. ${ }^{197}$ The international legal document being proposed must entrench the basic rights of people, a set of environmentally friendly practices, as well as corporations' basic privileges and their general obligations. Evidently, legal standards (particularly business related laws), as Jackson notes, 'are different in the various national legal systems around the world, so uniformity on an international level is not possible'. ${ }^{198}$ Thus, different countries have different domestic laws that govern the operations of corporations within their borders/jurisdictions; such laws are usually drafted in line with the overall developmental vision and agenda of the relevant State. Besides, there is diversity of cultural values and of differing levels of economic development. For these reasons, it would be challenging for the international community to have a law that reflects the provisions of participating countries' relevant domestic laws and the cultural values of all nations. However, these challenges are not unsurmountable.

As already noted, several international and regional ethical guidelines or codes of conduct and similar initiatives already exist for regulating the activities of MNCs; and many of these ethical guidelines are based on norms that have attracted wide consensus in the international community. ${ }^{199}$ The key problem with these existing guidelines and norms is that they are not binding, making it exceedingly difficult to enforce compliance. Indeed, there is a considerable measure of uniformity in the various corporate norms and guidelines that have been established or proposed for regulating the activities of MNCs. De George, for instance, recommends the following minimum standards regarding the operations of MNCs in host countries (particularly developing ones): the prohibition of activities that cause intentional harm/damage to people and the environment; ensuring that the good activities far outweigh any unintentional harm/damage; contributing to the host country's development; honouring basic human rights of workers and local communities; avoiding tax evasion or paying a fair share of taxes; and showing respect for local culture (provided that culture is itself ethical); among others. ${ }^{200}$ These proposals and similar existing norms could be adopted or considered for the formulation of the binding international corporate law being advocated. The document should also

\footnotetext{
196 Jackson (n 191); Gallegos and Uribe (n 192) 9; Silverman and Orsatti (n 9) 33; Vega and others (n 46).

${ }^{197}$ Duane Windsor, 'Defining the Ethical Obligations of the Multinational Enterprise' in W Michael Hoffman, Ann E Lange, David A Fedo (eds), Ethics and the Multinational Enterprise (University Press of America 1986) 71-74.

198 Jackson (n 191) 773.

199 See the Norms (n 54); the Principles (n 56); OECD Guidelines (n 60).

200 Richard De George, Competing with Integrity in International Business (OUP 1993) 45-56.
} 
prescribe hefty sanctions for non-compliance with stipulated fundamental ethical norms or codes of conduct; as well as realistic monitoring and enforcement mechanisms. The fact that the international community has managed to establish binding and enforceable international human rights legal documents which, to a significant extent, are achieving their intended purposes, shows that lack of uniformity may not be an insuperable hindrance to the effectiveness of the proposed law.

\section{B. International Corporate Court}

One of the hotly debated subjects in the fields of International Environmental Law and International Corporate Law is the question of creating an international corporate court to address the transgressions of MNCs and the relevance of such a court. Various academics have argued for or against such a proposal from various angles. ${ }^{201}$ However, even though this article endorses such an initiative, presenting a detailed and critical analysis of the subject is beyond its scope. There is no question that for an international corporate norms or law to achieve its intended purpose, it 'needs to be backed up by an effective mechanism for ensuring fairness and uniformity in the application, interpretation, and enforcement of those norms' or law. ${ }^{202}$ In other words, there should be a global corporate court. Such a court, as Jackson advocates, should have both civil and criminal jurisdiction, as well as jurisdiction over both legal entities (i.e. MNCs) and individuals. ${ }^{203}$ Thus, the world court on business and human rights being proposed could be competent to hear cases brought by victims (including States, groups and persons) of human rights abuses and environmental damage perpetrated by corporations, or by MNCs who may feel that they are unfairly treated by host countries. ${ }^{204}$ In an age in which numerous businesses are entering foreign markets and in which unscrupulous activities of international corporations continuously cause severe damage to the environment and violate the fundamental rights of local communities, '[i]t is appropriate to exercise direction and control in bringing about a new global legal order as a framework for multinational business. ${ }^{205}$

It has been argued by some academics that an international corporate court may have the capacity to hold to account only a handful of the tens of thousands of MNCs dispersed across the globe. Therefore, the creation of such an institution to enforce international corporate laws 'may only amount to a marginal contribution to the struggle for corporate accountability'. ${ }^{206}$ But as Jackson argues, it is unreasonable to expect the court to have the capacity to address all of the problems and harms caused by MNCs' activities. However, if it 'can at least provide an incremental benefit over either the status quo or alternative arrangements, then it is justified on utilitarian grounds. ${ }^{.207}$ Besides, it must be stressed that the creation of an international corporate court need not overthrow or thwart existing relevant domestic legal frameworks and efforts to regulate MNCs'

${ }^{201}$ Hasanali Pirbhai, 'Legitimacy Issues in Investor-Treaty Arbitration and How a Permanent Court May Be the Best Solution' (2018) 6(2) Groningen Journal of International Law 286; Luis Gallegos and Daniel Uribe, 'The Next Step against Corporate Impunity: A World Court on Business and Human Rights?' (2016) 57 Online Symposium 7; Jackson (n 191).

202 Jackson 774.

203 ibid.

${ }^{204}$ Gallegos and Uribe (n 193).

205 Jackson (n 191) 774.

206 Duruigbo (n 193) 254-255; see also Laura A Dickinson, 'Public Law Values in a Privatized World' (2006) 31 Yale Journal of International Law 382, 388.

207 Jackson (n 191) 761. 
operations. It should also not thwart the existing investment protection legal regime or arbitration tribunals. Instead, the proposed international court would complement and, to a significant extent, enhance the ultimate objectives of those national and regional efforts. ${ }^{208}$ Thus, such an international court may exercise jurisdiction only in cases where national and regional legal systems are, for whatever reasons, unwilling or unable to fulfil their obligation to address severe human rights and environmental concerns triggered by MNCs' activities; ${ }^{209}$ or if the relevant parties have reasons to fear that national or regional courts/tribunals will be excessively biased or are ill-equipped to handle the matter due to it complexities. ${ }^{210}$ The international corporate court being proposed may also serve as an appellate court and deal with cases brought before it from domestic courts or regional tribunals or arbitration panels. It will thus be down to the party seeking redress to decide where to initiate the legal proceedings - whether in a domestic, regional or the proposed international court. Of course, it would be unnecessary to initiate a claim at an international court (which may be more expensive) if the aggrieved party believes that domestic courts can effectively resolve the matter. Indeed, cases such as Lago Agrio, Chevron, Kiobel, Sarei, Bhopal and similar others would certainly not have dragged on for so long, and the outcomes may have been more satisfactory if they had been decided by, or the rulings had been contested in, an internationally recognised corporate court.

In instances where national legal standards do vary/differ, 'the [proposed] court can respect these variances by exercising its transfer jurisdiction, and by applying the substantive laws of the respective national legal orders where appropriate. ${ }^{211}$ When faced with a claim by an MNC against a host State, the international court may apply relevant aspects of the proposed binding legal document and pertinent existing investment protection treaties, as well as the relevant laws of the host State. As already argued, there is, in fact, a considerable measure of uniformity in the various corporate norms or laws that have been formulated for regulating the activities of MNCs.

It has also been suggested that, 'the imposition of direct obligations on private corporations, backed by an ... international mechanism to enforce those obligations', may be viewed by some countries as a significant disempowering and an interference in State sovereignty. ${ }^{212}$ In other words, some States, particularly advanced nations, may be reluctant to relinquish control over legal prosecution and adjudication to an international system/body, as that might be viewed as an interference with the concept of sovereignty which entails the exercise of absolute and unsupervised authority at the national level. ${ }^{213}$ But such an argument is based on an exaggerated conception of sovereignty that is not reasonable or realistic. ${ }^{214}$ This is because International Human Rights Law, International Humanitarian Law, and International Criminal Law already provide an elaborate system of norms and mechanisms which, to some extent, constrain the freedom of nation-states and agents acting on their behalf, to violate basic rights. For instance, the Universal Declaration of Human Rights and other international and regional human rights protection documents, as well as the decisions of relevant international institutions (e.g. courts, tribunals and commissions) have developed into both conventional and customary law binding, at least in principle, on all nations, and serving as checks and

\footnotetext{
208 ibid 758.

209 Gallegos and Uribe (n 193).

210 Jackson (n 191) 759.

211 ibid 773.

212 Dickinson (n 206) 388; see also Laura A Dickinson, 'Government for Hire: Privatizing Foreign Affairs and the Problem of Accountability Under International Law' (2005) 47 William \& Mary Law Review 135.

213 Dickinson (n 206); Dickinson (n 212).

214 Jackson (n 191) 764.
} 
balances on the excesses of national sovereignty. The fact that such international and regional legal frameworks have, to a significant extent, succeeded in enhancing human rights protection and promoting the dignity of the human entity by imposing significant constraints on the liberty of nation-states to violate the basic rights of individuals, justifies the institution of an international corporate legal framework to hold unscrupulous MNCs to account.

It is anticipated that the establishment of an international corporate court may face issues regarding funding, the role of States in proceedings, matters of access to the court (including costs and legal representation of victims), and the enforcement of its judgments. ${ }^{215}$ However, with extensive multi-stakeholder dialogues, negotiations, and compromises, a common ground could be found and a consensus reached prior to the establishment of the court. NGOs may also be encouraged to play significant roles in seeking justice for people adversely affected by MNCs' unethical activities in the proposed international court. MNCs that fail to comply with the judgement of the international court should have their assets frozen not only in the host State but also the home country or internationally. It is not uncommon for MNCs sued to dissipate their assets from beyond the jurisdiction of the court in order to frustrate a potential judgment/award against them, as was the case in Aguinda (Lago Agrio). To prevent such actions by MNCs dragged to the international court, asset freezing injunction/order that has either a domestic or a worldwide effect (as may be deemed appropriate) may be issued by the court prior to delivering its judgement. Evidently, the cooperation of, at least, the host and home countries would be vital in enforcing the international court's judgements against MNCs. International sanctions may be imposed on States that fail to comply with judgements delivered against them.

\section{General Benefits of a Binding International Legal Instrument}

One major problem observed by many experts is that MNCs tend to pack up and leave countries which adopt stringent corporate laws in search of more lenient laws and regulations, and to evade being sued for human rights violations, environmental damage, and other harms. ${ }^{216}$ As Shamir rightly puts it, 'MNCs are in a position to effectively escape local jurisdictions by playing one legal system against the other, by taking advantage of local legal systems ill-adapted for effective corporate regulation, and by moving production sites and steering financial investments to places where local laws are most hospitable to them' ${ }^{217}$ Having an international corporate legal document that prescribes ethical standards and sanctions for all MNCs, and a court that has the jurisdiction to deal with cases involving such corporations, irrespective of the territory in which they happen to operate, will compel chronically unscrupulous MNCs to change their behaviour and conduct their activities in ways that are acceptable and ethical.

Such an international framework will also help avoid the situation where host countries relax various primary regulatory frameworks (particularly ones relating to human rights and environmental protection, and the labour sector) in order to attract foreign investment. It must be admitted that various investment protection agreements that contain clauses prohibiting the host State from relaxing such important regulatory frameworks for foreign investment purposes do exist, but the extent of their effectiveness in ensuring ethical business practices has been minimal. Therefore, the international

\footnotetext{
215 Gallegos and Uribe (n 193).

216 Jackson (n 191); Shamir (n 193).

217 Shamir (n 193) 637.
} 
corporate legal framework being proposed is important to facilitate the regulation of MNCs in a more even-handed fashion than an exclusively national or regional arrangement allows. It will markedly clarify the rights and duties of MNCs and their obligations to respect human rights and preserve the environment. A corporate international court will particularly benefit less developed nations where regulatory and legal frameworks are usually insufficient and ineffective.

The creation of a standard international corporate legal framework will also benefit MNCs in a number of ways. It may reduce the burden of dealing with multiple countries in multiple domestic courts in the event of a human rights violation and environmental degradation related allegation and lawsuit. By extending their activities into other countries, MNCs confront an intricate web of national, regional, and global corporate standards and a wide array of obligations. Often times, such obligations run into conflict with each other, presenting difficult dilemmas for MNCs. ${ }^{218}$ A standard international legal system is therefore likely to significantly minimise this complication. Thus, such an international instrument will establish authoritative means to resolve conflicts arising from the law in different jurisdictions. ${ }^{219}$ An international corporate law and court will also ensure that MNCs operate on an even playing field. Besides, corporations that conduct operations in ways that are ethical and respect human rights are likely to gain competitive advantage over unscrupulous corporations, since the latter's activities will be sanctioned by a recognised international institution. ${ }^{220}$

Indeed, if MNCs 'are going to be permitted to reap the enormous benefits of an interdependent global economy, and take advantage of markets and workforces abroad, it is only fair and just that they accept the responsibility that goes with it - or be held liable when they do not. ${ }^{221}$ Considering that many governments, particularly those in developing countries, tend to be in bed with MNCs and shield them from 'prosecution' for wrongdoings, and knowing the massive environmental damage and human rights abuses that may result when MNCs' greed becomes aligned with government power, it is reasonable to support the idea of a stiffer international legal framework for regulating the operations of MNCs. Formulating binding international legal document(s) and instituting an international court that impose legal liability on global businesses will go a long way to discourage unscrupulous business activities and promote compliance with ethical standards.

\section{Conclusion}

This article has sought to critically evaluate the effectiveness of MNCs regulatory and accountability frameworks in promoting the preservation of the environment and the protection of fundamental human rights, at the national, regional, and international level. It has established that MNCs play a quite significant role in the economic and, in some cases, the infrastructural development of host States; they are very 'capable of much good: generating economic growth, increasing opportunity, and contributing financial investment in some of the world's least developed areas. ${ }^{222}$ However, it has been ascertained that the operations of MNCs have had and continue to have very negative and debilitating impact on the environment and human rights (such as water and air pollution, destruction of farmlands, child labour, discrimination, and torture, among others in host countries). It has been shown that a number of regulatory and

\footnotetext{
218 Jackson (n 191) 759.

${ }^{219}$ Gallegos and Uribe (n 193).

220 Jackson (n 191).

221 ibid 774.

222 Vega and others (n 46) 2.
} 
accountability frameworks dedicated at MNCs do exist, and these mechanisms have helped to raise awareness about the problem, and have encouraged some degree of ethics, respect, and circumspection in the behaviour and culture of MNCs in host States. The article has, nevertheless, strongly argued and demonstrated that the effectiveness of the relevant existing frameworks is far from approbatory, as gross and horrific environmental and human rights abuses continue unabated, and perpetrators (offending MNCs) go unpunished, particularly in less developed countries.

Unfortunately, many host governments (especially governments of developing countries) deliberately choose not to take strong and forceful action to hold MNCs accountable for their failure to adopt environmentally friendly practices and for violations of their human rights obligations, for fear of losing foreign investment to countries that enforce rights less stringently. This often gives MNCs the impetus to consistently disregard not only ethical practices to prevent environmental pollution but also fundamental human rights norms. Therefore, to effectively curtail the incessant human rights abuses and irreparable environmental degradations that result from the activities of MNCs, there should be enforceable environmental protection and human rights laws at the national level 'that are consistent with international norms and accompanied by strong, independent judiciary systems that provide concrete remedies for victims. ${ }^{223}$

It is noticeable that corporate accountability is an enormous challenge that cannot be effectively dealt with through the existing non-binding methods or frameworks. Since MNCs operate beyond State boundaries, attempts to institute a home State model of extraterritorial regulation to make MNCs accountable for human rights violations and environmental damage will always be inadequate. ${ }^{224}$ As Picciotto emphasises, 'although corporate codes have a legitimate place in helping to ensure compliance with standards through corporate networks, ... they should be more firmly anchored within a broader regulatory framework that establishes obligations as well as rights for business. ${ }^{225}$ It is therefore important that a comprehensive international treaty formulated within the UN systems clarify the human rights obligations of corporations and establish 'binding mechanisms that can provide remedies for victims in cases where it is impossible to prosecute victimizing companies in domestic jurisdictions. ${ }^{226}$

In a nutshell, the voluntary instruments and codes alone are qualitatively and quantitatively inept in achieving the results that they are meant to realise. It is therefore about time the unified international community moved towards the codification of binding instruments that are backed by a range of implementation and compliance mechanisms. ${ }^{227}$ The creation of an international court, with special all-encompassing jurisdiction over MNCs would, indeed, be a commendable endeavour.

$*$

\section{www.grojil.org}

\footnotetext{
223 Silverman and Orsatti (n 9) 33.

${ }^{224}$ Surya Deva, 'Acting Extraterritorially to Tame Multinational Corporations for Human Rights Violations: Who Should 'Bell the Cat'?' (2004) 5 Melbourne Journal of International Law 37.

${ }^{225}$ Picciotto (n 26) 133.

226 Silverman and Orsatti (n 9) 33.

227 Vega and others (n 46).
} 